\title{
The short and forgotten history of rubber in Madagascar: the first controversy between biodiversity conservation and natural resource exploitation
}

\author{
Pascal DANTHU 1, 2,3 \\ Herintsitohaina RAZAKAMANARIVO ${ }^{3,4,5}$ \\ Bernadette Deville-DANTHU ${ }^{2}$ \\ Lala RAZAFY FARA ${ }^{4}$ \\ Yannick LE RouX ${ }^{6}$ \\ Éric PenOt', \\ ${ }^{1}$ Cirad \\ Avenue Agropolis \\ 34398 Montpellier Cedex 5 \\ France \\ ${ }^{2}$ Cirad \\ Direction régionale \\ BP 853, Antananarivo \\ Madagascar \\ ${ }^{3}$ Cirad \\ DP Forêts et Biodiversité \\ BP 853, Antananarivo \\ Madagascar \\ ${ }^{4}$ École Supérieure des Sciences \\ Agronomiques \\ Département des Eaux et Forêts \\ BP 3044 \\ Antananarivo \\ Madagascar \\ ${ }^{5}$ Laboratoire des Radio-isotopes \\ Route d'Andraisoro \\ BP 3383 \\ Antananarivo \\ Madagascar \\ ${ }^{6}$ Projet Forma \\ SCAC \\ Ambassade de France à Madagascar \\ present address: \\ Ministère des Affaires Etrangères \\ 29 rue de la Convention \\ 75732 Paris Cedex 15 \\ France \\ ${ }^{7}$ Cirad \\ UMR Innovations \\ 34398 Montpelier Cedex 5 \\ France
}

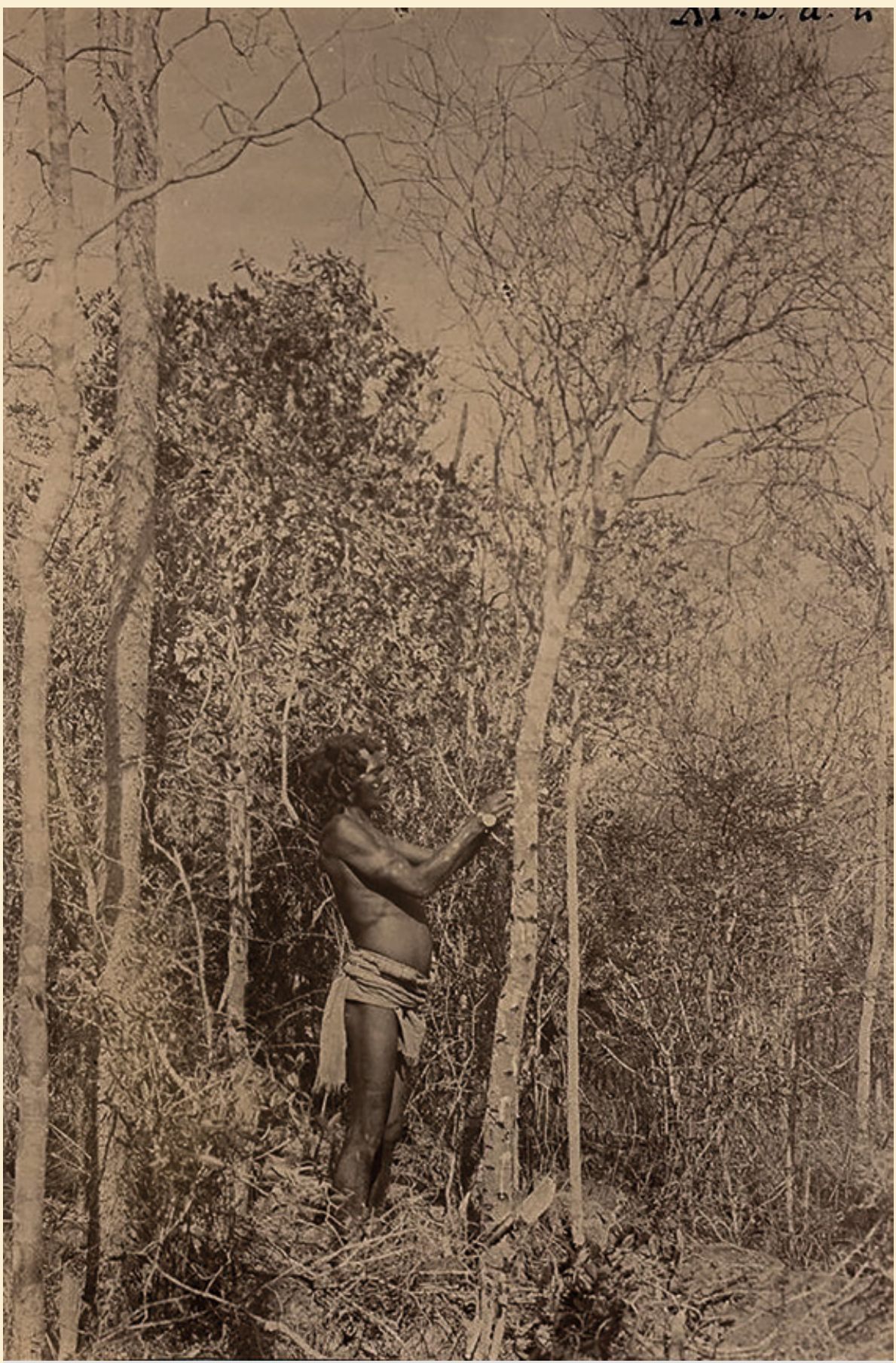

Illustration 1

A remarkable specimen of Euphorbia intisy and collector near Fort-Dauphin (not dated) (Doc. XI. Ba $\mathrm{n}^{\circ}$ 48, Fonds Grandidier, Parc botanique et zoologique de Tsimbazaza, Antananarivo, copyright PBZT) 


\section{LA COURTE HISTOIRE OUBLIÉE DU CAOUTCHOUC À MADAGASCAR : LA PREMIÈRE CONTROVERSE ENTRE CONSERVATION DE LA BIODIVERSITÉ ET EXPLOITATION DES RESSOURCES NATURELLES}

Madagascar fut entre 1891 et 1914 une zone de production de caoutchouc sylvestre destiné à l'exportation vers l'Europe. Le poids de Madagascar dans le commerce mondial resta toujours modeste, mais cette activité eut des conséquences écologiques importantes. De nombreuses espèces endémiques furent exploitées, dans une optique de productivité immédiate et maximale sans prise en compte de notion de gestion durable. Cet épisode représentant l'un des premiers cas d'exploitation des ressources biologiques malgaches à des fins industrielles a été l'un des éléments déclencheurs de la prise de conscience de la valeur de la biodiversité malgache et des menaces induites par des activités humaines mal contrôlées. Il aboutit à la promulgation d'une législation très répressive et coercitive à l'endroit des populations locales désignées comme principales responsables. Mais les naturalistes jugèrent les décisions politiques inefficaces. Ils développèrent alors un discours volontairement alarmiste et catastrophiste ayant pour but de faire réagir les politiques jugés trop laxistes. Discours d'ailleurs pris à contre-pied lorsque l'effort de guerre relança la filière caoutchouc malgache entre 1942 et 1945 . Cet épisode fut un élément déclencheur de la création, dès 1927, d'un réseau d'aires protégées, faisant de Madagascar un pionnier en Afrique. Parallèlement la domestication des espèces caoutchoutières malgaches et/ ou l'introduction des espèces à fort potentiel furent promues. Cependant, l'émergence du caoutchouc issu de l'hévéaculture asiatique fit rapidement retomber l'intérêt commercial du caoutchouc malgache, épargnant ainsi les forêts de la Grande île. Ainsi, c'est le réalisme économique qui condamna la filière devenue non rentable et assura la sauvegarde des espèces à caoutchouc malgaches plutôt que les discours des naturalistes, la création d'aires protégées ou la promulgation de textes répressifs.

Mots-clés : histoire environnementale, exploitation des ressources naturelles, produit forestier non ligneux, caoutchouc naturel, discours des naturalistes, effort de guerre, Madagascar.

\section{THE SHORT AND FORGOTTEN HISTORY OF RUBBER IN MADAGASCAR: THE FIRST CONTROVERSY BETWEEN BIODIVERSITY CONSERVATION AND NATURAL RESOURCE EXPLOITATION}

From 1891 to 1914, Madagascar was producing forest rubber for export to Europe. Although Madagascar's contribution to the world rubber market was very modest, this episode had major consequences for the island's ecology. Many endemic species were exploited, with a view to maximising short-term productivity with no consideration for sustainability. This was one of the first cases of biological resource exploitation in Madagascar for industrial purposes, and was one of the factors that triggered awareness of the value of Madagascar's biodiversity and the threats to which it might be exposed because of badly managed human activities. Highly repressive legislation was introduced and imposed on the local populations, who were considered mostly to blame for these threats. However, naturalists considered these policies to be ineffective and responded in deliberately alarmist terms designed to provoke a reaction from allegedly over-lenient policy-makers. Their position was caught on the wrong foot in 1942-45, when the war effort revitalised Malagasy rubber production. Nevertheless, the episode was one of the factors behind the creation, in 1927, of a network of protected areas managed by naturalists, making Madagascar a conservation pioneer in Africa. Meanwhile, efforts were made to promote the domestication and/or introduction of high-potential rubber species. With the emergence of Asian rubber production, however, all attempts at rubber cultivation in Madagascar were abandoned, thus sparing Madagascar's forests from further destruction. This episode shows how Malagasy rubber species survived not thanks to naturalist discourse, the creation of protected areas or the enforcement of repressive legislation, but because an unprofitable sector was abandoned for reasons of economic realism.

Keywords: environmental history, natural resource exploitation, non-timber forest products, natural rubber, naturalist discourse, war effort, Madagascar.

\section{LA BREVE Y OLVIDADA HISTORIA DEL CAUCHO EN MADAGASCAR: PRIMERA CONTROVERSIA ENTRE CONSERVACIÓN DE LA BIODIVERSIDAD Y EXPLOTACIÓN DE RECURSOS NATURALES}

Entre 1891 y 1914 Madagascar fue una zona productora de caucho silvestre destinado al mercado europeo. A pesar del modesto peso que siempre ocupó Madagascar en el comercio mundial, dicha actividad tuvo importantes consecuencias ecológicas. Se explotaron muchas especies endémicas buscando una productividad máxima e inmediata sin integrar la noción de manejo sostenible. Este episodio supone uno de los primeros casos de explotación de los recursos biológicos malgaches con fines industriales y fue uno de los desencadenantes de la toma de conciencia del valor de la biodiversidad de Madagascar y de las amenazas generadas por actividades humanas mal controladas. Esto llevó a la promulgación de una legislación muy represiva y coercitiva destinada a la población local, considerada como principal responsable. Sin embargo, los naturalistas juzgaron las decisiones políticas ineficaces e intencionadamente adoptaron un discurso alarmista y catastrofista para provocar la reacción de unos representantes políticos considerados demasiado permisivos. Dicho discurso tomó un giro inesperado cuando se reactivó el sector del caucho para contribuir al esfuerzo bélico entre 1942 y 1945. La explotación del caucho fue uno de los desencadenantes, en 1927, de la creación de una red de áreas protegidas que convirtieron a Madagascar en una pionera en África. Al mismo tiempo, se potenció la domesticación de especies de caucho malgaches y/o la introducción de especies con alto potencial. Sin embargo, la aparición del caucho procedente de cultivos asiáticos hizo decaer rápidamente el interés comercial del caucho malgache, protegiendo así los bosques de la isla. Así pues, fue el realismo económico y no los discursos de naturalistas ni la creación de áreas protegidas o la promulgación de leyes represivas quien condenó un sector que no era rentable y garantizó la protección de las especies de caucho de Madagascar.

Palabras clave: historia ambiental, explotación de recursos naturales, productos forestales no madereros, caucho natural, discursos de las naturalistas, esfuerzo bélico, Madagascar. 


\section{Introduction}

Up until 1900, the world's natural rubber was produced entirely through collections from wild plants. The commercial product was thus generically known as forest rubber (as opposed to plantation rubber). Following the discovery by Charles Goodyear, at the turn of the $19^{\text {th }}$ century, that the process of vulcanisation (mixing with sulphur prior to heating) allowed rubber to retain its elasticity and resistance, industrial development, more specifically that of tyre manufacturing, created a strong and constantly expanding demand (Bouvier, 1947; Serier, 1993; IRSG, 1996; Mooibroek and Cornish, 2000).

At that time, the market in forest rubber, obtained from a diverse range of species, including lianas, shrubs and trees, was supplied by three continents: America, Asia and Africa (figure 1), where the production zones were limited to tropical regions. Ficus elastica was exploited in the British and Dutch possessions of Southeast Asia (India, Burma, Java, Borneo, Malaysia), essentially prior to 1870 (Jumelle, 1903; Lavauden, 1941; Serier, 1993). At the end of the $19^{\text {th }}$ century, Amazonia, and in particular the regions of Para and Manaus, became the principal regions for the production and exportation of rubber from the hevea tree (Hevea brasiliensis). But, after having represented more than half of the world's production, making towns like Manaus fleetingly rich, Amazonian production plummeted discernibly after 1910 as Asian rubber production took off (Coïc, 2000) (figure 1). Other species, in other regions, were also solicited, such as Manihot glaziovii, or Castilloa elastica, originally from Mexico, and for some time, were considered to produce the best rubber (Weinstein, 1983; Homma, 1992; Serier, 1993; Coïc, 2000).

The production of rubber collected from the African continent was transient, beginning around 1880 (Delmas and Duffart, 1908b; Chevalier, 1926) and lasting until around 1910. At its peak in 1900, it represented around a third of the world's production (figure 1). Numerous forest and savanna species supplied the African production, amongst which the main ones were Futumia elastica, Clitandra cymosa and Landolphia heudelotii (Chevalier, 1921, 1926; Serier, 1993).

However, from the middle of the $19^{\text {th }}$ century, it became apparent that the production of forest rubber would be inadequate to provide for the growing requirements of European and American industrialists, in particular with the development of the car and tyre industries after the First World War. Hence, the idea was conceived to domesticate and cultivate the main rubber species. After numerous attempts, frequently recounted (Bouvier, 1947; Chevalier and Le Bras, 1949; Serier, 1993), the first hevea rubber trees were established in 1876 in Ceylon. Henceforth, cultivation spread to the whole of the British and Dutch possessions in Southeast Asia at the turn of the century. Rubber was introduced in Malaysia, Indonesia and Thailand. In Sumatra, hevea seeds had been introduced through estates in North Sumatra and by Chinese traders into the South in the first decade of the $20^{\text {th }}$ century. In Borneo, the first seedlings had been introduced in 1882 (Dove, 1995). Seeds were distributed to the 'natives' in 1908 by the Sarawak Government. In Kalimantan, Chinese merchants, Catholic missionaries and a Dutch private company ("Nanga Jettah") introduced rubber seeds in 1909 (King, 1988).

The first recorded production from Asian plantations (Chevalier and Le Bras, 1949), in 1900, was modest (four tonnes) but from that point on it increased rapidly. Figure 1 shows that from 1915, forest rubber was swept aside by productions from the Asian hevea plantations and jungle rubber (agroforestry system where rubber is allowed to grow with secondary forest [Penot, 2001]). By 1930, they were supplying more than $95 \%$ of the world's requirements.

A regular, low cost supply, with long term stability, of a product conforming to optimal technological qualities, rapidly got the better of a production varying in quality and quantity, the scarcity of which was being predicted by botanists (Bourdariat, 1911; Serier, 1993).

The short-lived history of African forest rubber has been long forgotten. And yet, it still serves as a valuable example of an economic sector which was established and then abandoned as a direct result of overexploitation of a natural resource. This history also marks the emergence of an environmentalist and conservationist discourse, which is still current. These are the elements that this article aims to elucidate, focusing particularly on the case of Madagascar.

Between 1891 and 1914, forest rubber was collected and exported from Madagascar. It occupied a minor place on the world market, even though rubber was one of the island's principal export products. As noted by the Governor

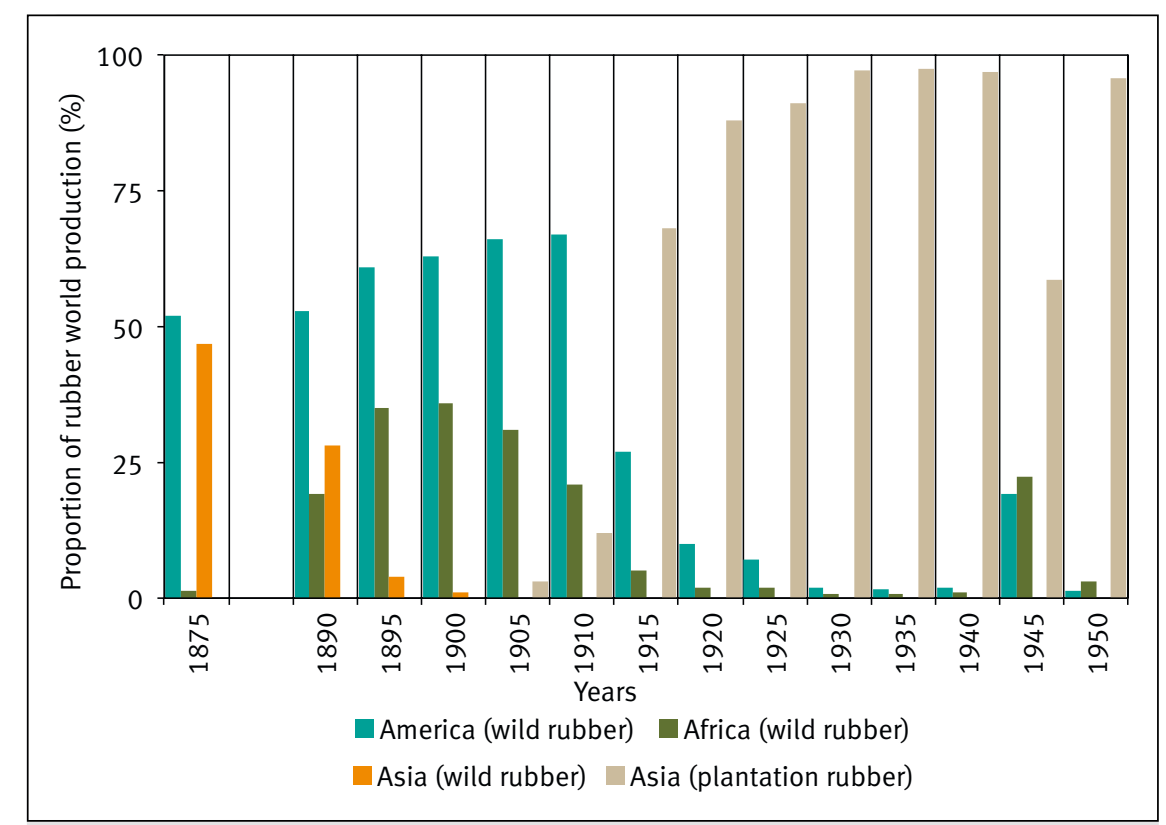

Figure 1.

Relative importance of the various continents in

the production of natural rubber from 1895 to 1950

(from Delmas and Duffart, 1908a, 1908b; Fayol, 1909;

IRSG, 1996). 
General Galliéni (1908), "rubber of which we find excellent species in the forests of coastal and intermediate regions, is one of Madagascar's best sources of wealth, especially since it has become a prime industrial component in the manufacture of bicycles, cars and surgical instruments". Its extraction had major consequences at a biological level but also contributed to an increasing awareness amongst naturalists of the degradations that the Malagasy forests, remarkable for their biodiversity and endemicity, were suffering (Baron, 1890; Perrier de la Bâthie, 1921). This study describes, therefore, in detail the processes which, (i) allowed Madagascar to participate for the first time in the world economy, (ii) engendered what was presented as an ecological catastrophe and, (iii) uphold the conservationist discourse. And as such it describes the emergence of the controversy between the exploitation and valorization of the island's biological resources and the conservation of its biodiversity, a controversy which is still active to this day (Gade, 1996; Myers et al., 2000; Pollini, 2011; Scales, 2012).

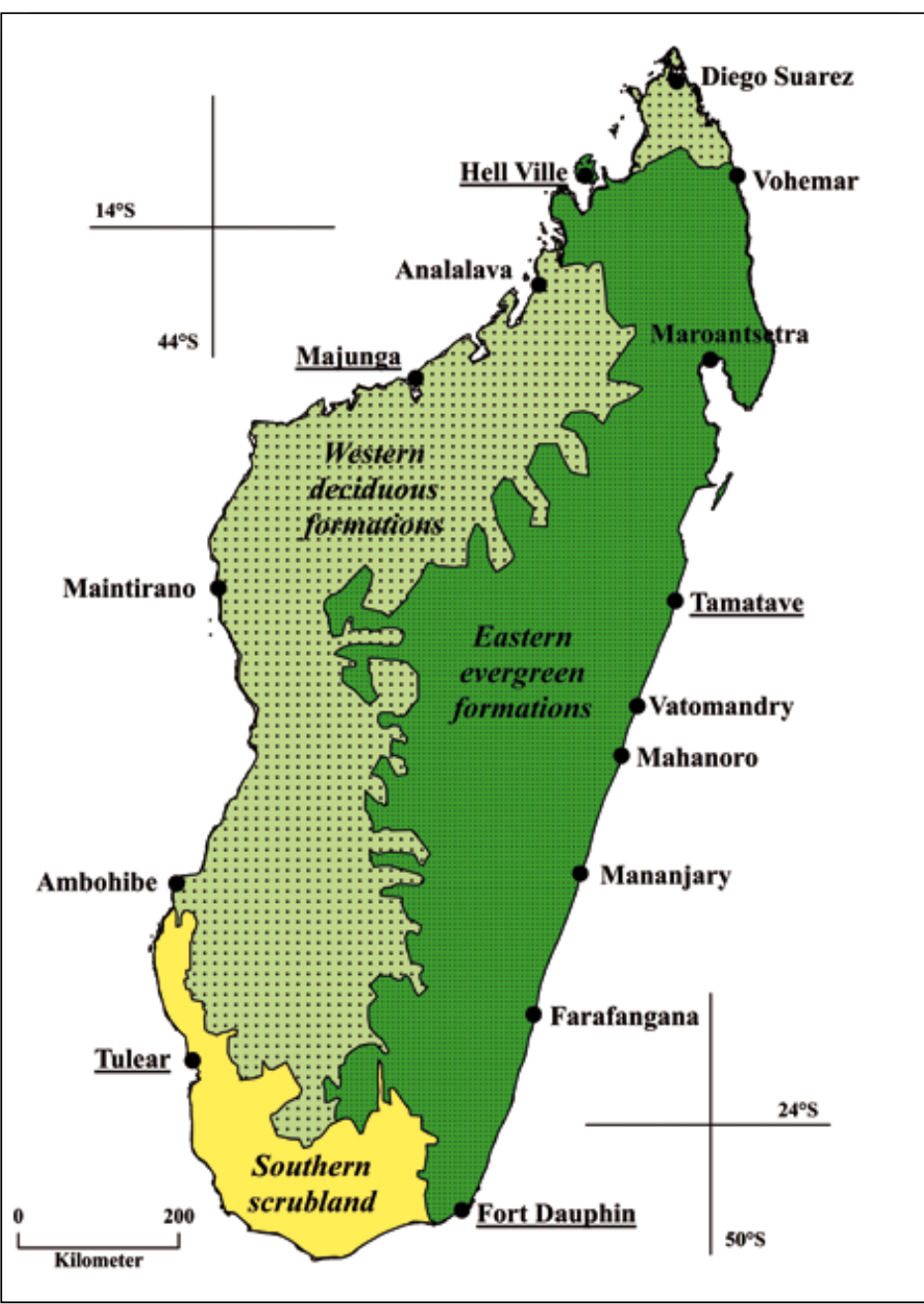

Figure 2.

Distribution of the three major Malagasy vegetation zones and the ports for the exportation of Malagasy rubber between 1891 and 1920; the names were those current during the colonial period and the most important ports are underlined (from the Bulletin économique de Madagascar, 1900 to 1911; Humbert, 1955; Bégué, 1966; Gautier and Goodman, 2003).

\section{Main features of the Malagasy rubber sector}

The objective in this first part will be to describe the place occupied by the rubber sector in a local and international context both from an economic and a biological perspective.

\section{A modest sector on a global scale but of local importance}

The use of rubber in Madagascar was reported as early as 1791 by the explorer Abbé Rochon in his "Voyage à Madagascar et aux Indes orientales", where he made reference to "the milky fluid that the islanders extract from the trees they call finguiere, which gives when coagulated the remarkable substance known to naturalists as gum elastic. The elastic properties of this resinous gum have more recently been put to good use in the arts. In surgery it has already been used to great advantage in perfecting such things as bandages and catheters." Rear admiral Dumont d'Urville described in his "Voyage autour du monde" (he put into port at Tamatave in 1830) "voaene, a sarmentose shrub which affords gum elastic". The first exportation of Malagasy rubber to Europe, however, appears to have occurred in 1870 (Decary, 1962). Production increased, after 1882, with the exploitation of Landolphia, a liana from the east coast, which was exported to Germany and Great Britain. But, it was not until 1891 onwards, when the quality of rubber sourced from Euphorbia intisy (illustration 1, figure 2) in the region of Fort-Dauphin was recognised, that the exploitation of rubber became significant (Prudhomme, 1899/1900; Zimmermann, 1899; Piolet, 1901; Decary, 1962; Tixier, 1982; Serier, 1993).

Figure 3 shows that this production peaked in 1906 and 1910, the only years for which records show a yield in excess of a thousand tonnes. Despite this, Malagasy production represented no more than 5 to $6 \%$ of total African output and less than $2 \%$ of world output.

The production of rubber in Madagascar was directly dependant on the political events which marked the beginning of French rule. The exploitation of rubber was coetaneous with the wars and insurrections which preceded and followed the voting of the act dated $6^{\text {th }}$ August 1896 declaring Madagascar a French colony (Galliéni, 1908). The production curve of Malagasy rubber is a stark reflection of the ups and downs of the island's military and political circumstances. Thus, the insurrection which broke out in the south of the island at the beginning of 1897 explains the drop in harvest and exportation during this period (Prudhomme, 1899/1900) (figure 3). This region was the field for military operations again in 1900-1902, to which fall in production recorded at this time can be partly attributed (Poisson, 1908; Brown, 2000). On the other hand, the sharp fall in exports from Madagascar (as well as Africa) in 1908 resulted from the financial crisis that rocked America in 1907-1908, which can be put down in part to the poor sales of cars and over stocking of primary materials in previous years (Fayol, 1909; Fauchère, 1911).

Malagasy production diminished to almost zero from 1916. 


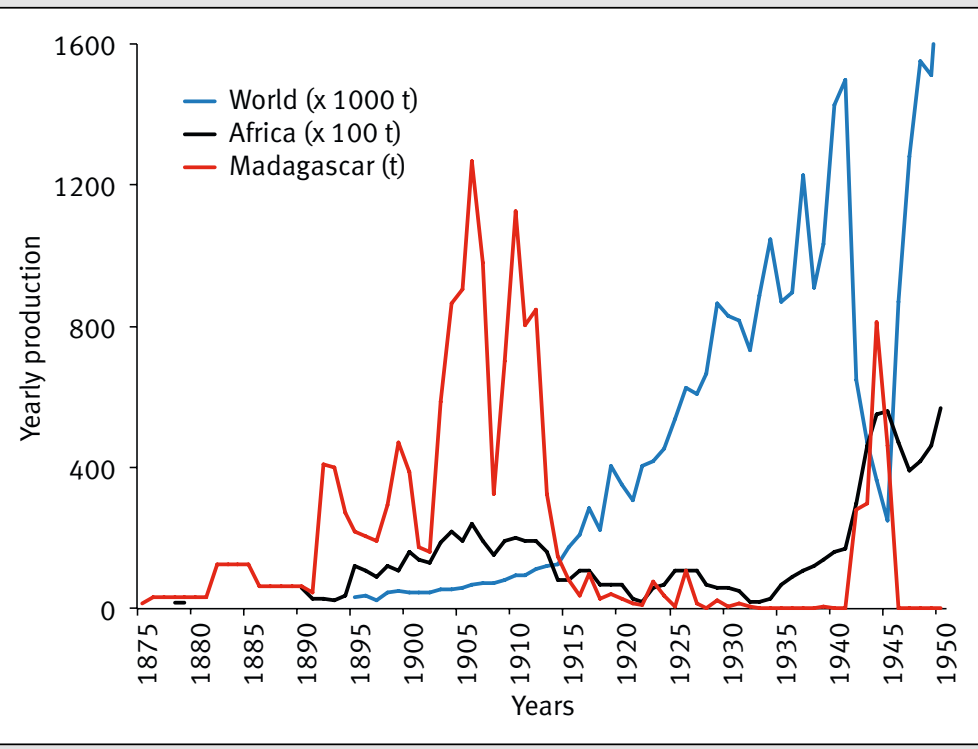

Figure 3.

Evolution of the production of natural rubber in Madagascar (in tonnes) between 1875 and 1950, compared with the evolution of African production (in hundreds of tonnes), and world production (in thousands of tonnes) (from Griess, 1907; Delmas and Duffart, 1908a, 1908b; Galliéni, 1908; Fayol, 1909; Loisy, 1914; Canaby, 1932; Lavauden, 1941; Chevalier and Le Bras, 1949; Tixier, 1982; IRSG, 1996).

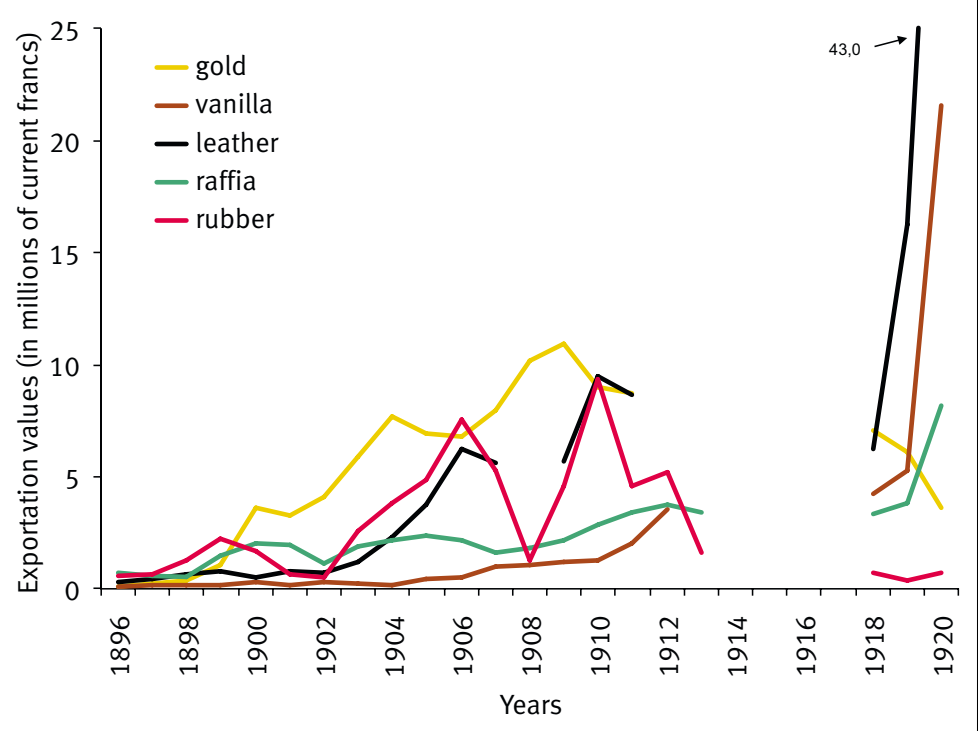

Figure 4.

Value of rubber exports from Madagascar (expressed in millions of current francs), compared with the value of Madagascar's main export products between 1896 and 1920 (from Griess, 1907; Galliéni, 1908; Bulletin économique de Madagascar, 1900 to 1927; Loisy, 1914).
Figure 4 compares the value of rubber exports from Madagascar with the value of other principal exports during the period in which rubber production was significant in Madagascar. Gold was the main export product. Its value increased steadily until 1909 before gradually diminishing. Before the war, leather and raffia were major resources for Madagascar, whilst vanilla played a marginal role. After the war, these three products became the island's principal exports. The curve of exports linked to rubber was highly erratic. These variations reflect the previously mentioned political events. However, on four occasions (the years 1898, 1899, 1906 and 1910) rubber was Madagascar's number one export product.

Malagasy rubber was essentially destined for the European market. Germany and Britain were the two main importers prior to French colonisation, after which production was shipped to the French ports (Le Havre, Bordeaux, Marseille), as well as Liverpool, Hamburg and Antwerp (Besson, 1908; Durand, 1908; Claude, 1909; Canaby, 1932).

Numerous Malagasy ports served as exit points for rubber. Tonnages exported varied considerably from year to year, but as a general rule, the main points of export were Tamatave on the east coast, Majunga and Hell-Ville (Nosy Be) on the west coast, Fort-Dauphin and Tuléar in the south (figure 2).

\section{Exploitation implicating all the Malagasy ecosystems}

At the outset of the $20^{\text {th }}$ century, the forest zones of Madagascar covered between a fifth and a third of the island's surface (Perrier de la Bâthie, 1936; Coudreau, 1937; McConnell, 2002). The presence of lianescent, arborescent and shrubby rubber producing species was charted in all the forest ecosystems: the evergreen humid forest in the east and north (Prudhomme, 1899/1900; Thiry, 1903; Vergely, 1907; Jumelle and Perrier de la Bâthie, 1909, $1910,1912)$, the dry deciduous forests in the west (Jumelle, 1901; Louvel, 1910; Jumelle and Perrier de la Bâthie, 1911; Perrier de la Bâthie, 1912) and the xerophilous scrubland in the south (Chapotte, 1898; Vacher, 1907; Poisson, 1908) (figure 2).

Figure 5 takes into consideration the respective proportions of these three major vegetation zones in the production of Malagasy rubber. It shows that between 1897 and 1910, production was divided relatively equally between the three ecological regions. The forest in the east had a share which, depending on the year, varied from 22 to $52 \%$, that of the western forest from 25 to $31 \%$, whilst the southern bush had a share of between 17 and 34\%.

The entire species of Malagasy rubber belong exclusively to three botanical families: Asclepiadaceae, Apocynaceae and Euphorbiaceae. Table I shows that the Apocynaceae belong, for the 
most part, to the Landolphia genus (voahena, or fingotry, as it is known in Malagasy, the species most certainly described by Abbé Rochon [1791] and Dumont d'Urville [1848]), Mascarenhasia (guidroa, barabanja and hazondrano), and Plectaneia, and are present in the evergreen forest in the east and deciduous in the west. The Asclepiadaceae are represented by species belonging to five genus, Cryptostegia (lombiro), Gonocrypta, Pentopetia, Marsdenia and Secamonopsis, which are present in the west and south. The Euphorbiaceae are represented by two arborescent species: Euphorbia pirahazo in the west and E. intisy (herotsy) (illustration 1) in the southern bush (Baron, 1890; Girod-Genet, 1898; Lecomte, 1899; Zimmermann, 1899; Jumelle, 1901; Drake del Castillo, 1902; Thiry, 1903; Canaby, 1932; Boiteau, 1943; Comité du Caoutchouc, 1943; Decary, 1962, 1966).

The majority of rubber species are endemic to Madagascar, with the exception of Cryptostegia grandiflora, which is also present in other islands in the Indian Ocean (Jumelle, 1912), and Mascarenhasia arborescens, also distributed in East Africa (Schatz, 2001). Often, even the genera are endemic, as is the case for Gonocrypta, Pentopetia, Secamonopsis and Plectaneia (Boiteau, 1943; Mabberley, 1987; MBG, 2010). On the other hand, the Landolphia species is very widely represented amongst the rubber species exploited in dry and tropical Africa, as far as Senegal (Delmas and Duffard, 1908b; Fayol, 1909; Etesse, 1913; Chevalier, 1926; Chevalier and Le Bras, 1949).

The quality of rubber produced was highly species dependant. Hence the majority of Mascarenhasia produced good quality rubber with a high latex content (40-45\%) and low resin content (5-6\%). They were marketed under the name of "Madagascar Niggers". "Palay Rubber" was extracted from the Cryptostegia species. The brands known as "Majunga Rose" and "Madagascar Pinky" were associated, on the whole, with rubber from the best species of Landolphia from

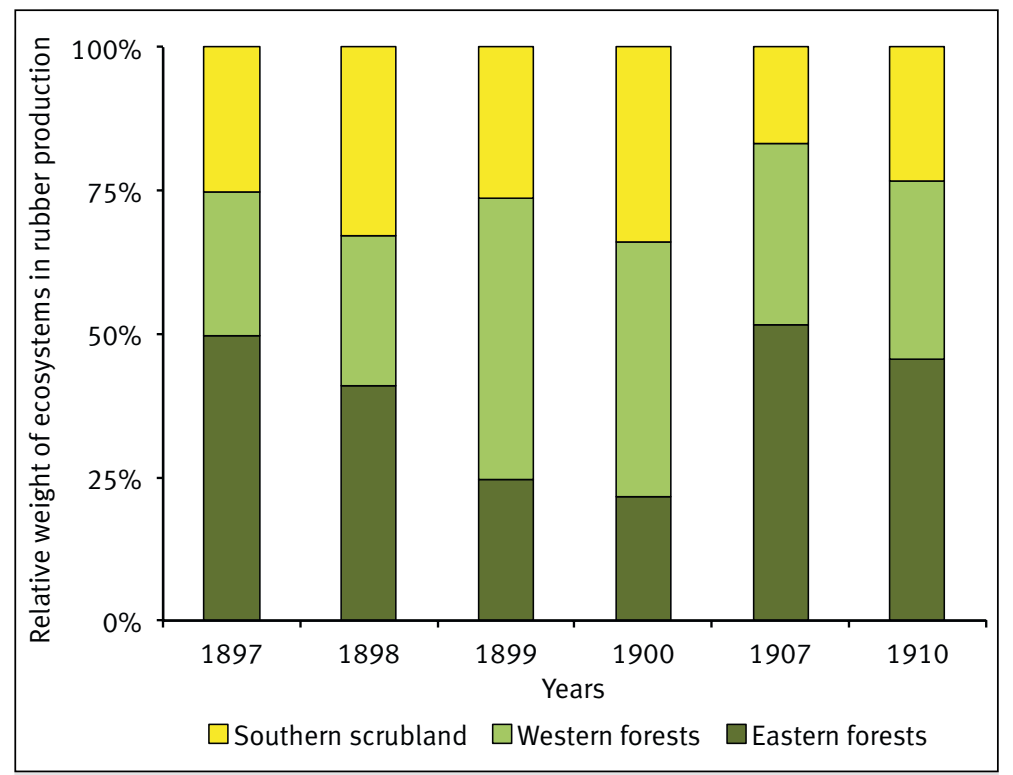

Figure 5.

Share of each of the three vegetation zones (see figure 2) in the production of rubber, calculated on the basis of exports declared by each exit port in the different zones of Madagascar (from the Bulletin économique de Madagascar, 1900 to 1911). the west of the island, and for which the value on the European market was close to that of Para (derived from Brazilian hevea rubber), which was (and remains) the gold standard at the time (Bourdariat, 1911; Boiteau, 1943; Fournier et al, 1990). Gonocrypta grevei (kompitso in Malagasy) also produced a good quality rubber. However, the best Malagasy rubber was obtained from Euphorbia intisy (illustration 1), which had a very high latex content (44\%) and extremely low resin content (around $1 \%$ ). The other species were of low value, producing rubber with a high resin content, which was often sticky (Constantin and Galland, 1907; Boiteau, 1943).

\section{"A fine example of lack of foresight and a destructive economy" (Decary, 1926)}

The preparation of rubber required a series of simple stages, nonetheless decisive in the quality of the finished product and for the conservation of the biological resource: extraction method, coagulation method, drying and storage of the rubber. These procedures were carried out by Malagasy collectors in the forest. The rubber was then sold in the villages or towns to locally based dealers, who were Malagasy, Indian, Chinese or European.

In actual fact, the potential financial gain generated by the sale of rubber was an incentive for many local peasants to set themselves up as collectors. Whereas the lack of skill and the concern for making quick, short-term financial gains led to short cuts in the harvesting methods, endangering the producing species, in the process. This exemplifies what Decary (1926) defined as "A fine example of lack of foresight and a destructive economy".

\section{Outdated modes of preparation}

In Brazil, seringueiros (tappers) initially locate the trees scattered throughout the forest and create trails connecting them. Then, two or three trails connecting 60 to 150 trees are established (a job which takes several months). When the time comes to harvest the rubber, they travel the length of each trail alternatively, early in the morning, making an incision in the trunks (avoiding damaging the vascular cambium). Then they travel the trail again to harvest the latex which has collected in the bowls under the incisions (Dean, 1983). This method allows trees to remain productive for several years, thus assuring their survival.

In Madagascar too, it was generally recommended that trees be tapped, as this was the only procedure considered compatible with sustainable conservation of the resource (Louvel, 1910; Bourdariat, 1911). However, it was certainly not always the case (table I).

Although tapping was also recommended by some for the lianas (Girod-Genet, 1898), the most commonly used method consisted in dragging the lianas to the ground, chopping them off at ground level and cutting them into 50 to $60 \mathrm{~cm}$ logs. These were put on 
an improvised stand to bleed, the latex being collected in a trough according to the diagram in illustration 2 (Thiry, 1903; Rey, 1905; Griess, 1907; Louvel, 1910; Fauchère, 1911; Bourdariat, 1911). Louvel (1910) explained the use of this method as follows: "It's not out of vandalism or a love of destruction, that the natives have always [...] cut the lianas into logs, as generally claimed, but because they had practically no other means of harvesting." This method was potentially ecologically sustainable, because the species in question puts out abundant suckers (Griess, 1907; Louvel,
1910). In spite of this, yields of rubber remained poor. This led Perrier de la Bâthie and Jumelle (1907), and Louvel (1910) to recommend chopping the liana fragments (by crushing or pounding), a method which doubled, even quadrupled the yield in relation to bleeding the logs.

The object of coagulation was to concentrate the rubber particles in emulsion in the latex in order to create a solid transportable mass (Chevalier and Le Bras, 1949). This operation occurs naturally for some latex, such as $E$. intisy, but for many others it was necessary to resort to the use of

Table I.

Taxonomy (updated by MBG, 2010), biological types, latex extraction method and rubber qualities (+: low; ++: medium; +++: high) of the main rubber species exploited in Madagascar (according to Jumelle, 1901, 1903; Dubard, 1906; Constantin and Galland, 1907; Hamet and Josse, 1913; Perrier de la Bâthie, 1910, 1912; Fauchère, 1911; Jumelle and Perrier de la Bâthie, 1908, 1909, 1911, 1912; Loisy, 1914; Boiteau, 1943; Léandri, 1952).

Family

Species

Plant type

Eastern evergreen forests

Apocynaceae

Apocynaceae

Asclepiadaceae

Euphorbiaceae

\begin{tabular}{|c|c|c|}
\hline & & \\
\hline & Landolphia myrtifolia (Poir.) Markgr. & Liana \\
\hline & Landolphia tenuis Jum. & Thin stemmed liana \\
\hline & Mascarenhasia arborescens A. DC. & Tree/shrub \\
\hline & Mascarenhasia lisianthiflora A. DC & Tree \\
\hline & Plectaneia elastica Jum. \& H. Perrier & Liana \\
\hline & Plectaneia thouarsii Roem. \& Schult. & Liana \\
\hline \multirow[t]{6}{*}{ Asclepiadaceae } & $\begin{array}{l}\text { Cryptostegia madagascariensis Bojer } \\
\text { ex Decne. }\end{array}$ & Liana \\
\hline & Gonocrypta grevei Baill. & Liana/shrub \\
\hline & Marsdenia verrucosa Decne. & Liana \\
\hline & Pentopetia elastica Jum. \& H. Perrier & Liana \\
\hline & Pentopetia grevei (Baill.) Venter & Liana/shrub \\
\hline & Secamonopsis madagascariensis Jum. & Liana/shrub \\
\hline Euphorbiaceae & Euphorbia pirahazo Jum. & Large tree \\
\hline
\end{tabular}

Landolphia mandrianambo Pierre

Western deciduous forests

\begin{tabular}{lll}
\hline Landolphia gummifera (Poir.) K. Schum. & Large liana \\
\hline $\begin{array}{l}\text { Landolphia mandrianambo Pierre } \\
\text { Landolphia myrtifolia (Poir.) Markgr. }\end{array}$ & Liana \\
\hline Mascarenhasia arborescens A. DC. & Tree/shrub \\
\hline Mascarenhasia lanceolata A. DC. & Small tree \\
\hline Mascarenhasia macrosiphon Baker & Tree \\
\hline Mascarenhasia rubra Jum. \& H. Perrier & Tree
\end{tabular}

\section{Southern scrubland}

Asclepiadaceae

Euphorbiaceae
Cryptostegia grandiflora (Roxb.) R. Br. Gonocrypta grevei Baill. Pentopetia grevei (Baill.) Venter Secamonopsis madagascariensis Jum. Euphorbia intisy Drake

\section{Latex extraction method}

\section{Quality of rubber}

Draining logs from stems

Draining logs from stems

Draining logs from stems

Felling and cutting/stripping

Uprooting and stripping bark from stems and roots

nd

Felling and tapping

$+$

nd

$++$

$+++$

$++$

nd

+++

Draining logs from stems

Draining logs from stems
$+$

$++$

$+++$
Draining logs from stems

Felling and cutting/stripping

Uprooting and stripping bark from

stems and roots

Draining logs from stems

Draining logs from stems

Draining logs from stems

Bark stripping

Tapping fruit

Draining logs from stems

nd

Tapping stems and fruit

Tapping, felling and cutting

nd

Bark stripping

nd

Tapping stems and fruit

Tapping, cutting trunk and roots

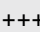

$++$

$+++$

$+$

$+$

$+$

$++$

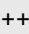

$+$

$++$

$++$

Liana

Liana/shrub

Liana/shrub

Small tree 
chemical, mechanical or thermal processes. In Madagascar, collectors used heating, or else the addition of dilute sulphuric acid, or concoctions of various fruits (lemons, tamarinds, and baobabs), sea salt or urine (Armand, 1901; Piolet, 1901; Rey, 1905; Bourdariat, 1911; Loisy, 1914; Comité du Caoutchouc, 1943).

It should not be overlooked that the work of the collectors was extremely gruelling and performed by people who often lived in extreme poverty, surviving on a very low income. Lecomte (1899), a colonist from Farafangana, estimated that collectors of hazondrano (Mascarenhasia sp.) "[...]were subjected to long treks in the forest, often travelling for a month, to amass a man's load of perhaps 25 to $30 \mathrm{kgs}$ ". Whilst Prudhomme (1899/1900) described the collector in the following terms: "The Malagasy who goes off in search of rubber [...] does not burden himself with a mass of tools, he simply equips himself with a specially formed machete which he calls antsibé. If he is careful, he also takes along a cast iron cauldron to prepare his meals and coagulate the latex,

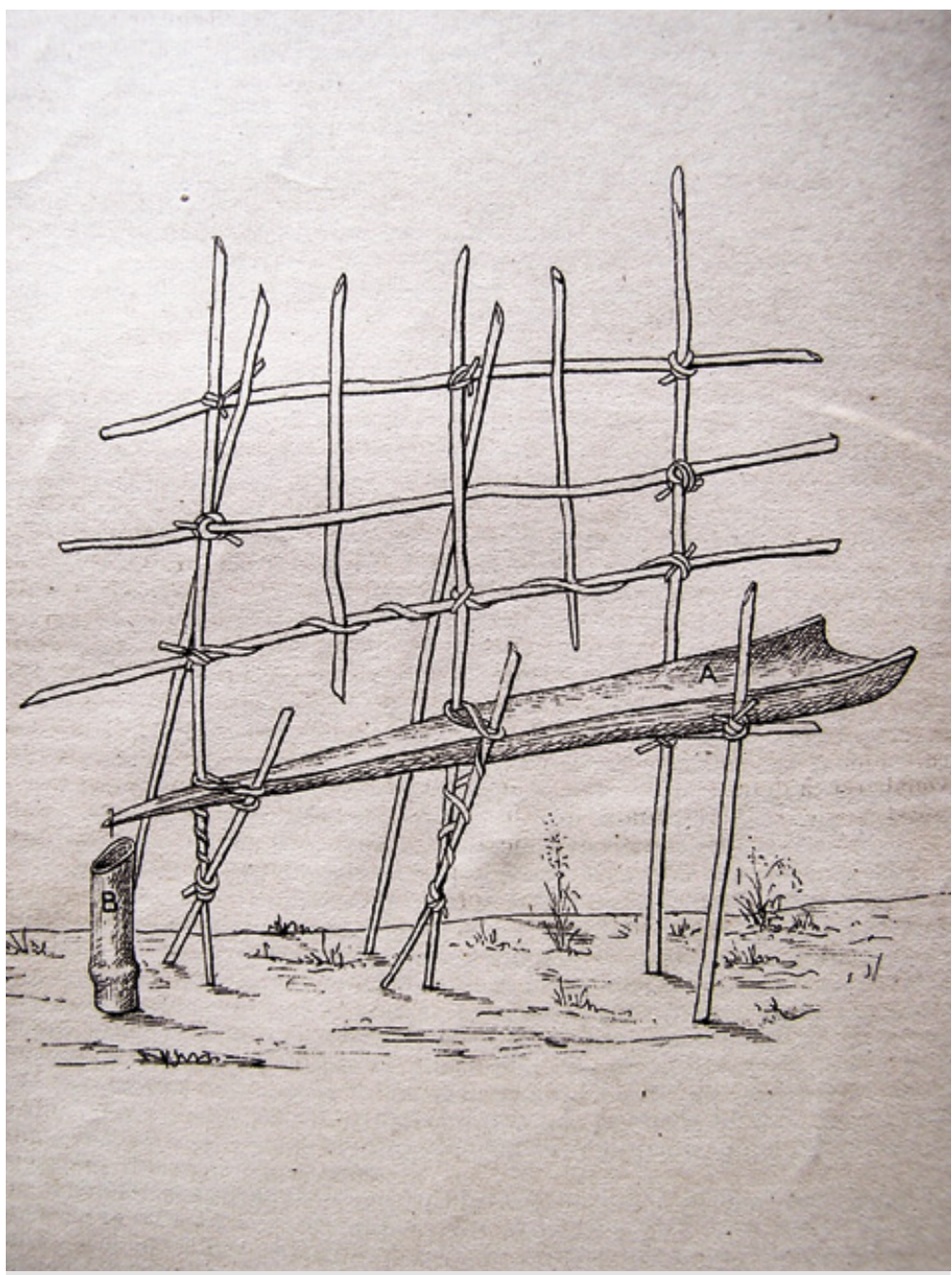

Illustration 2.

Diagram of the device for collecting the extract of segments of liana, as used by the collectors (Thiry, 1903).

Photo P. Danthu. as well as a vial of sulphuric acid diluted with water or a stock of sea salt, but in most cases, he considers this material too burdensome [...] assured that he is of finding all he needs in the forest to perform his work, such as lemons and tamarinds for the coagulation, a container to collect the latex".

Another example of a method used in the south of the island consisted in scooping out a cup in the ground at the foot of the tree, which was then bled. The latex ran down the trunk and was collected in the hollow, and then mixed with sand and debris (Chapotte, 1898; Vacher, 1907).

Usually the rubber produced this way was formed into balls the size of two fists and sold to the dealers (GirodGenet, 1898; Besson, 1908; Decary, 1962).

\section{Exploitation gone awry}

But these methods fairly rapidly fell by the wayside. According to Lecomte (1899), the natives initially bled the trees, but faced with the increase in demand, "exploitation turned into a devastating fever", in which the tree was felled, the trunk surrounded with dead wood, which was ignited. The effect of this was to coagulate the latex on the bark, which was then hammered off, producing in the process latex full of impurities (plant debris, sand, gravel...). In 1911, Fauchère pointed out that the rubber hunters as a rule didn't fell the trees but inflicted wounds which often resulted in their death. He also condemned the fact that "When lianas were involved, [...]. It was not uncommon to see the roots dug up". Girod-Genet (1898) spoke of "barbaric procedures", a concept which was echoed by numerous authors such as Prudhomme (1899/1900), who talked about "irreparable damage caused by the Negroes' carelessness and the collectors' greed", and Hamet and Josse (1913) who decried "the state of devastation" of the rubber groves.

The care (or moreover the lack of care) taken during harvest depended partly on the collectors. Their motivations varied, but, as a general rule, it can be said that rubber was not a tradition for any Malagasy, which Vacher (1907) translated saying that "most of our natives [...] were unaware of the existence of rubber trees in their region". However, certain ethnic groups were used to seeking out all or part of their means of subsistence from the forest. Such was the case, for instance, with the Tanala and the Sakalava who turned their hand to rubber collecting quite naturally and without changing their way of life (Tralboux, 1902; Vergely, 1907). But for others, collecting rubber became a subsidiary activity, the main motivation of which was to earn income. Thus, the Antaimoro became rapidly aware of the gains that could be made from this new activity, so as to "improve their savings, their well-being, their rice paddies and their herds" (Vergely, 1907). Likewise, for the Antandroy, most of whom were cattle breeders, the motivation to convert to rubber collecting was the creation of a tax on cattle in 1903, "anxious to keep their enormous herds intact, they turned to rubber for the cash they needed" (Vacher, 1907). Durand noted in 1908 , moreover, that the "natives" very often only turned to collecting rubber when the tax became due. Fremigacci (1998) furthermore confirms that forest populations were only able to pay the tax from the proceeds from the collection 
of forestry products: rubber but also raffia, wax and orsein. This would appear to have been the primary motive of collectors in French continental Africa, too (Chevalier, 1921). Farmers expected an income from rubber which would cover the cost of the tax, but in French Equatorial Africa, collectors were required from as early as 1904 to neglect their food crops to devote themselves to collecting rubber resulting in a decline in agriculture, and subsequent famine (Chevalier, 1921). There appear not to be any reports of this type of situation in Madagascar. However, it has to be said that in Madagascar, even if the rule remains largely fictional, user rights were only authorised to cater for personal needs and not for commercial purposes, resulting in what Fremigacci (1998) referred to as "an economy of delinquency".

This lack of tradition and the monetary incentive explains why the exploitation methods used by the collectors were often careless, because the object was to ensure a harvest and one with a high return (Thiry, 1903; Perrier de la Bâthie, 1912; Boiteau, 1943).

The collectors were quick to come up with strategies to increase the weight of rubber sold to dealers, whilst minimising the amount of time spent harvesting. This chapter in the history deals with the frauds which were widely documented by traders, administrators and scientists. The most common fraud consisted in adulterating the balls of rubber by bulking up their weight with foreign objects such as stones, bark and sand (Baron, 1890; Durand, 1908; Bourdariat, 1911). Another trick was to soak them in water. An even more subtle ruse cooked up by some collectors involved mixing the latex of rubber species with that from widely available, poor quality species (such as Ficus melleri, Plectaneia elastica, Plectaneia thouarsii and Marsdenia verrucosa), increasing the collected weight in the process, but reducing the quality of the end product (Griess, 1907; Jumelle and Perrier de la Bâthie, 1908; Poisson, 1908; Louvel, 1910; Boiteau, 1943). It seems as though this adulteration rapidly became standard practice, and that a large proportion of the Malagasy rubber harvest was subject to these types of fraudulent practice. However, the same practices were observed in Brazil (Dean, 1983), Asia (Penot, 2001) and in French West Africa, despite an initiative by the colonial powers to establish a "rubber training programme" for collectors (Chevalier, 1921).

However, it is worth noting that the intermediaries in the sector never placed a high value on quality in the rubber delivered to them. Vacher (1907) pointed out that the best prepared rubber was never better recompensed than the latex coagulated on the ground, "there was no incentive for the native to abandon his primitive extraction method"... and so, they persisted in their corrupt practices. Bührer (1909) estimated that it was impossible to improve the quality of the rubber produced whilst "remaining in this vicious circle which says to the buyer: 'the product is always of poor quality, so I'll pay the minimum for it' and to the producer: 'I'm paid the minimum, so never mind the quality".

\section{Endangered species?}

From 1898, Girod-Genet was writing of Euphorbia intisy: "this plant has become extremely rare". What is more, he announced, without any compunction, the imminent destruction of the ecosystems and the disappearance of the rubber species. As early as 1899, the geographer Zimmermann confirmed the increasing scarcity of this species, which was responsible for the "sudden commercial prosperity of Fort-Dauphin between 1890 and 1896. Unfortunately, in a matter of years the reserves from entire centuries have been destroyed, leaving intisy, which grew right up to the walls of Fort-Dauphin, only to be found to the west of Mandrare or at some five to six days walk inland. At the same time, rubber production, which equalled 400 tonnes in 1892 and 1893, fell noticeably to 168 tonnes in 1896".

Perrier de la Bâthie, in a report to the director of the Department of Colonisation in October 1912 relating to a prospecting mission between Fenerive and Maroantsetra, raised the alarm over the "complete and irremedial dissappearance of the whole rubber species in the east" (Perrier de la Bâthie, 1912a).

Professor Lecomte (1929) of the Académie des Sciences spoke of "plants currently or previously used by man", and in particular of Euphorbia intisy, that "have almost entirely disappeared due to thoughtless devastation". Bigorne, in 1931 , reviewing the products derived from the Malagasy forest, quoted "for the record" the rubber species, "which have almost totally disappeared", and Decary (1966) stated with regard to Euphorbia pirahazo that this tree "has not been reviewed by botanists for a fair few years". Today, E. intisy species does not appear to be particularly endangered, but $E$. pirahazo is always considered critically endangered (Haevermans, 2003; IUCN, 2015).

The culprit was clearly singled out as the native. For Girod-Genet (1899), "the majority of plants containing rubber, resins or latex of use to industry were subject to barbaric exploitation by the natives. Not only were they expected to produce far greater annual yields than they should have been, but they were even destroyed to obtain, in one go, the greatest amount of saleable product". Lieutenant Bührer (1909) denounced "the lamentable exploitation of rubber plants by the natives". In 1911, Bourdariat spoke of the Malagasy forest as a "precious capital abusively exploited by the natives". Although, sometimes, a more subtle and less Manichean stance was taken. Prudhomme (1899/1900) and Perrier de la Bâthie (1931) went as far as to admit that the colonists were as much to blame as the natives. Likewise, Decary (1926) held "natives and Europeans", "whites and blacks" equally responsible for pillaging the resource. This view is confirmed by Fremigacci (1998) who shows that, only too often, the colonist is both the backer and the beneficiary of these collections. 


\section{Conservation and valorization of the species from utopia to inapplicability}

Acknowledgement of the disappearance of rubber species, and more generally the decline of the Malagasy forests, provoked a very swift reaction (Jarosz, 1993; Kull, 2000). Politicians put forward a legislative corpus aimed at protecting the species and organising sustainable management of the ecosystems. The agronomists devised a set of strategies to develop cultivation of the most interesting species, in order to perpetuate the sector in Madagascar.

\section{Repressive but unenforceable policies}

Where the rubber species were concerned, the first legislative decisions were taken as early as 1897. An order dated $3^{\text {rd }}$ July required of each producer that he "be obliged to plant every year, at his own expense, three times as many precious species as the number of trees felled in the course of the year". The ministerial order dated $10^{\text {th }}$ February 1900 , which set out the Malagasy forestry regulations, specified the methods of bleeding rubber trees and lianas "in order to avoid destroying the producing plants". It also decreed that felling or uprooting rubber plants could be punishable with imprisonment for between one and ten days. These points were confirmed in the order dated $20^{\text {th }}$ September 1907 regulating the exploitation of forestry products and by the ministerial order of $28^{\text {th }}$ August 1913 relating to the forestry regulations in Madagascar. This reiterated the requirement for planting in each farmed plot a minimum of 150 rubber trees or lianas per hectare, instituting an annual tax of ten centimes per hectare farmed, payable in advance and provided for a penalty of up to five years imprisonment for "anyone damaging, burning, ransacking or destroying [...] forests managed or artificially repopulated with rubber species".

But the majority of decisions, as repressive as they were, remained ineffective, due to the administration having too few agents to enforce them: in the years between 1896 and the 1920 s, the number of forestry officers appointed to the island varied from one to two and the number of officials, from two to five (Lavauden, 1934). Moreover, Captain Jeannot (1901) was under no illusion as to the impact these laws would have on the rubber collectors: "it would be unfeasible to compel natives as undisciplined as those involved in the harvesting of rubber to abide by rules, even the simplest. [...] A rubber hunter, camped out in the depths of the forest, is only concerned with his own immediate needs and will never take on a process which will yield less and create extra work".

\section{Short lived agronomic research}

From the agronomist's point of view, scarcity of the resource led to the development of a double approach in Madagascar: (i) attempt to refine methods for preserving and managing the natural ecosystems rich in local rubber producing species, (ii) promote the introduction and acclimation of exotic species with an already identified potential.
These two approaches are neither original, nor specific to Madagascar (Bergeret, 1993; Pouchepadass, 1993). They correspond to the two major lines of action that scientists and colonists were applying at the turn of the $20^{\text {th }}$ century. It was their ambition, out of a sense of national duty, to promote exploitation of the colonies' resources to the advantage of the homelands' emerging industries (Chevalier, 1930, 1946; Lavauden, 1941; Bonneuil and Kleiche, 1993). Madagascar then became, in the same way as the whole of the newly colonised and pacified regions, a land ripe for the discovery of natural wealth, scientific exploration, domestication of exotic natural environments and agronomic innovation (Bergeret, 1993; Pouchepadass, 1993).

The work undertaken was founded on a principle declared by Jean Dybowski, the director of the Colonial Garden in Nogentsur-Marne, in France (1897): "Certain species are bled for rubber. Fibres from the palm trees are harvested for raffia [...]. And one becomes so used to harvesting products which come spontaneously that sometimes one deduces from it that this is what rational exploitation of our colonies consists of [...] It is not enough to satisfy oneself with harvesting products that are freely available, one must cultivate". To quote yet another, the agronomist and statesman, Eugène Tisserand, wrote in 1902: "the forests that produced gutta-percha are becoming depleted; the rubber lianas under the devastating machete of bush runners are receding in the face of the progressing invasion; if we don't hurry to repopulate, it won't take much for our most precious species to disappear, exhausted by excessive exploitation" (from Bonneuil and Kleiche, 1993).

And so it was that Madagascar and the rubber species represented a vast subject of investigation during the early part of the $20^{\text {th }}$ century. The research proposals were directed three ways: (i) conservation and management of forest ecosystems rich in rubber species, (ii) domestication and cultivation of local species and (iii) introduction of exotic species with previously identified potential and for which cultivation was already controlled.

Delmas and Duffart (1908b) recommended the first solution: "The forest, alone, in its integrity - such as nature made it with its undergrowth, its dead layer, even its parasites (plant and animal), thinly yet robustly populated with 100 to 150 rubber plants per hectare - is and should remain the supreme resource of rubber production". In the Menabe (western Madagascar), this proposal began to take effect at the beginning of the $20^{\text {th }}$ century. The administration tried to bring about the transfer of forestry management to local populations and farmers: "The forests in each region will be divided between the villages of that region, each village fixing the boundaries of its 'faritany', the village chief will then allot shares of the forest to his people". The administration compelled the Sakalava collectors to regenerate the stands exploited by propagating the major rubber species from layering or cutting. And so, in March 1905, 7,000 layers were planted, each one registered in the owner's name (Rey, 1905). These proposals were upheld by the authorities since the order dated $3^{\text {rd }}$ July 1897 and the ministerial order of the $28^{\text {th }}$ August 1913 obliged farmers to aid the regeneration of exploited species. These attempts at managing the ecosystems rich in rubber species were, nonetheless, to no avail. 
Other foresters, such as Thiry (1903), appeared to be optimistic about the feasibility of cultivating Malagasy species: "Madagascar is particularly privileged. The best of our lianas, which up until the present day have remained unidentified, even botanically, are [...] liable to hold their own against those rubber species currently mostly highly considered. Landolphia is easy to cultivate [...], and suffers less hazards than any other cultivation yet attempted on the island". Thiry estimated at 400,000 hectares the surface area of forest in the east suitable for planting and considered cultivating Malagasy lianas to be more economically beneficial than planting major exotic species (Hevea, Castilloa, Ficus or Kickxia [other name Futumnia]). This point of view was also defended by Bourdariat (1911) and Louvel (1910), who advocated more than an assisted regeneration system, but envisaged implementing real "rubber reserves" by domesticating local species and, more specifically, lianas of the Landolphia species. In fact, a large base of preliminary knowledge was obtained, at that time, from various studies on the aptitude to propagation (sowing, layering, cutting), types of behaviour and methods of exploitation of these species (age of exploitability, harvesting heights, management of suckers...) and even on the likely economic profitability of such reserves. This idea was picked up on by Perrier de la Bâthie and Jumelle (1907) who considered it possible to create groves of Malagasy rubber species from scratch in savanna zones. Griess (1907) proposed, along the same lines, to launch the cultivation of Euphorbia intisy, for which cutting was reputedly very easy (a point which was never confirmed).

However, all these fine projects were never implemented. The risks in launching a new cultivation and the need for investment with only longterm returns must have discouraged the colonists.

This explains why some envisaged the introduction and creation of plantations of rubber species according to the model implemented in Southeat Asia (Griess, 1907; Bourdariat, 1911; Fauchère, 1911; Perrier de la Bâthie, 1912; Hamet and Josse, 1913). The candidate species featured Hevea brasiliensis (illustration 3), but also the ceara rubber tree (Manihot glaziovii), Castilloa elastica, Funtumia elastica from Africa, as well as Ficus elastica from Asia.

Introduction trials were carried out under various edaphic and climatic conditions in the years from 1888-1902 (Prudhomme, 1899/1900; Perrier de la Bâthie and Duchêne, 1908; Fauchère, 1911) often with contradicting results. According to Perrier de la Bâthie and Duchêne, (1908), the ceara rubber tree developed satisfactorily in the Marovoay region. Whilst Perrier de la Bâthie (1912) considered hevea and ceara took well in the Sambirano. Fauchère (1911) even pointed out that "it seems that these trees, if correctly cultivated, should be able to provide yields which compare to those obtained in the countries where they are cultivated".

However, Hamet and Josse (1913) were much more sceptical, concluding that in Madagascar, "it has not yet been proven that the
American species are able to acclimate profitably". Prudhomme (1899/1900) was altogether doubtful on the success of cultivating rubber species. He advised, moreover, for the east coast "cultivation which was better known and with more guaranteed success, such as that of vanilla, cocoa, cloves and coffee".

It was, on proof of evidence, the latter option which turned out to be justified: no economic development ever came of these trials. Little more than 800 hectares of plantation were counted in 1908 (Fauchère, 1911) and no rubber producing programme ever saw the light of day in Madagascar.

Some small scale plantations were established in the 1930 s on the eastern and northwest coasts but these rapidly disappeared due, in all likelihood, to the high prevalence of typhoons (Donques, 1975). Madagascar was evidently not a good candidate for hevea rubber tree culture compared to Southeast Asia or West and Central Africa even if some people believed in the idea (Lecat, 1951). Furthermore, two potential opportunities which might have led to a large rubber development programme failed. The first was the resource's scarcity during the Second World War (see infra), which could not be exploited as there was too little time for plantations to be established. The second was the loss of Indochina by France in 1954, which prompted French rubber companies to diversify their supply to Africa, but with Madagascar too far away, it offered less advantages in comparison to the Ivory Coast or Cameroon.

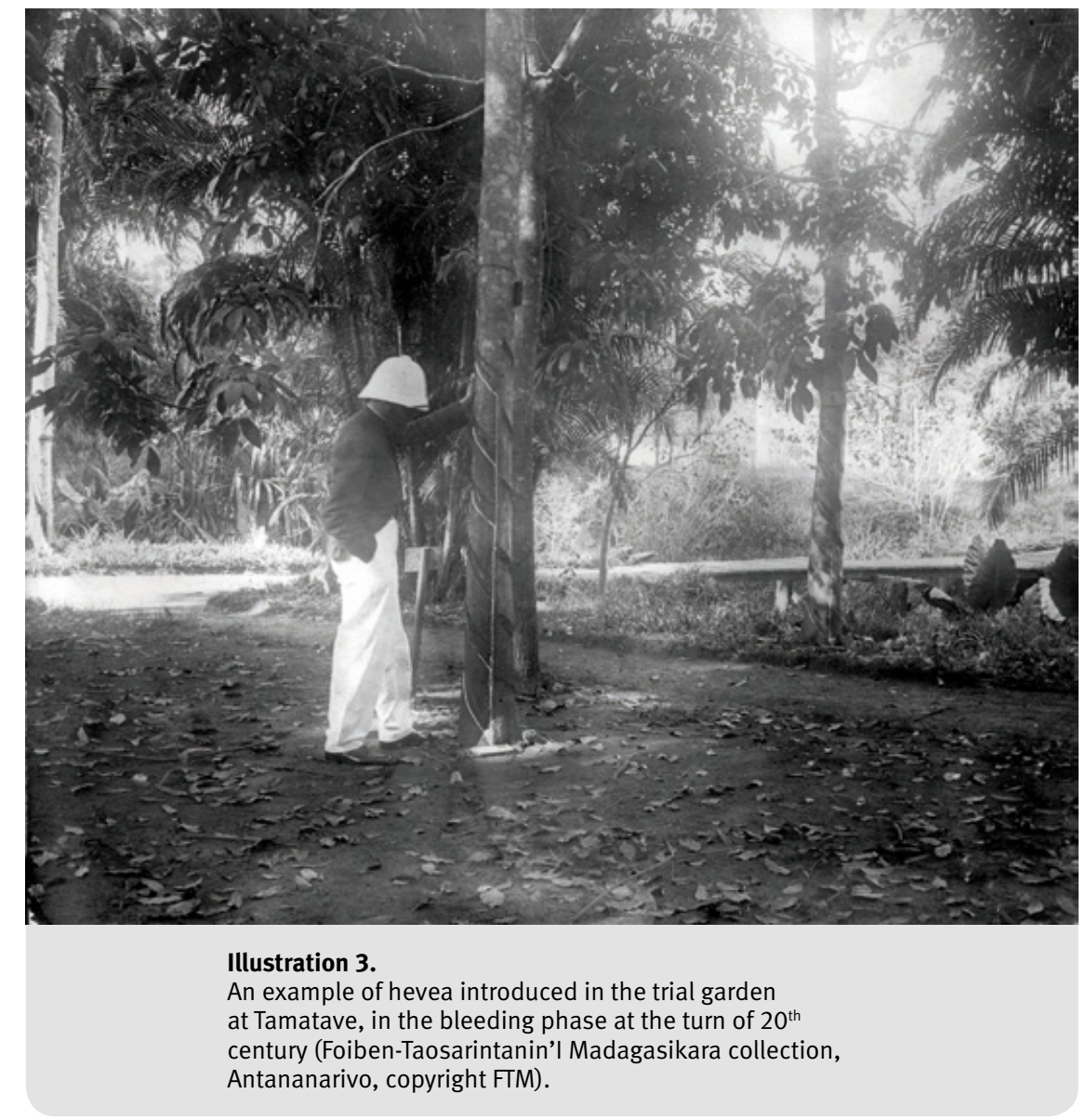




\section{The naturalists get involved to compensate for the incompetence of the authorities}

Naturalists have always reprimanded slash and burn cultivation (tavy) traditionally practised by Malagasy peasants and considered a prime factor in deforestation (Perrier de la Bâthie, 1921; Humbert, 1927; Gade, 1996; Kull, 2000). The practices related to rubber collection were the first cause of destruction of the ecosystems for economic ends. They added a new dimension to the concerns of nature conservationists, who strongly doubted the colonial administration's capacity to ensure the preservation of Madagascar's biological heritage, because as Perrier de la Bâthie (1931) highlighted without any illusions, "in Madagascar more than anywhere, there is a gulf separating the written law from its effective application".

This situation arose generally from the naturalists' awareness of the overexploitation and degradation of the Malgasy forests but it can be assumed that their stance was influenced by the issue of rubber.

Two direct consequences of this distrust can be highlighted, which are not inconsequential for the Malagasy environmental policies of that era.

The first is the emergence of a very pessimistic discourse on the protection of Malagasy biodiversity. It should not be overlooked, and it is rarely documented, that the catastrophist tone of this discourse was intentionally over-stated, as it was intended, in the minds of the naturalists, to convince a body (administrators and civil servants) judged "too often apathetic and cautious", as reported by Perrier de la Bâthie (quoted by Lacroix, 1938). This position, moreover, converges with another quote, typical of Perrier de la Bâthie, who in 1928 dramatised the situation by proposing to abandon the forest to the exploiter because in any case, "the climatic conditions, the customs of the natives, the self interest of the peasants and the indifference of the leaders, all condemn the forest to extinction, anyway". In actual fact, the naturalists seemed not to trust the politicians to take and apply the conservative measures they were recommending. In their eyes, the political powers appeared very amateurish in the way they went about implementing the regulations in order to ensure the conservation of the biological heritage. So, Lavauden, in 1931, claimed that "it's about time the authorities took stock of the real social danger in neglecting these massive degradations and in abandoning [...] the evolution of the vegetation cover to the vagaries of habit, preconceptions and trends." In the same spirit, Roger Heim (1935), the deputy director of the Muséum d'Histoire Naturelle, in Paris, wrote: "It is likely that one day, in Madagascar, as elsewhere, the entire responsibility for technical services will finally be entrusted to men who are specialised and competent. But when it comes to the forest the implications are particularly serious in that the solution cannot wait. It's now or never; either there is an immediate improvement or there won't be any at all".

Hence, and this is the second consequence, it is out of defiance of the legislation in place and those responsible for applying it that the naturalists imposed the idea of creating "nature sanctuaries". These were intended to "provide lifelong protection against exploitation", and were therefore established in uninhabited areas, with difficult access, in order to dissuade any "temptation to cultivate or exploit, and hence any complaints from present or future occupants" (Lacroix, 1938). Perrier de la Bâthie (1912a) suggested as early as 1912 the creation of a network of forestry reserves which would serve as "refuges" for the precious species and in particular rubber species. The first network was established in 1927 and consisted in ten reserves covering a surface area of approximately 350,000 hectares. It had been conceived with a view to preserving evidence of primitive fauna and flora. These reserves were free from all rights of usage; hunting, fishing and mining were all forbidden, as was picking wild plants (article 4 of the ministerial order dated $31^{\text {st }}$ December 1927). The order made provision for the reserves to be placed under the auspices of the Muséum d'Histoire Naturelle, in Paris, in order to ensure the longevity of the action (Petit, 1928; Lecomte, 1929). This was because, had they had been entrusted exclusively to the forestry service, they "would be left to themselves and there would soon be nothing more left of them but a puff of smoke and a pile of ashes" (Perrier de la Bâthie, 1931). In this, Madagascar was at the vanguard, as one of the first countries in the world to possess a network of wildlife sanctuaries, and in Africa, was preceded only by the Albert National Park in the Belgian Congo (Perrier de la Bâthie, 1931) and the Kruger National Park in South Africa (Humbert, 1933; Anonymous, 2006).

It would be nonetheless stretching the imagination to suggest that the mere creation of the first Malagasy reserves was influential in protecting the Malagasy rubber heritage and thus able to explain the regeneration of its production capacity in 1943. The surface area of these reserves remained static at 353,579 ha $(0.006 \%$ of the island's surface) until the Second World War, and then only increased from 1956-8 (ANGAP, 2001). Whilst one of the reasons put forward for their installation was, as stated by Lecomte (1929), to combat the "disappearance of plants currently or previously used by man", as in the case of Euphorbia intisy, "which was virtually wiped out in a matter of years", the size of the reserves and the limited means employed for overseeing and managing them, as reported by Perrier de la Bâthie (1931), will have most certainly reduced the effectiveness of the political measure.

\section{When the conservation of heritage is solvable in the national interest}

However, certain factors in the history of Malagasy rubber show that scientific discourses are not infallible. The following historical points demonstrate how the naturalists, from 1943 onwards, under obligation to have Madagascar participate in the war effort were compelled to contradict their own discourse. They were forced to admit that the catastrophism they had been disseminating since the 1920 s concerning the destruction of the rubber species was unfounded. And worse still, they became actively involved in the promotion of rubber collection. 
It is possible to detect, in figure 3, a brief yet distinct recovery in Malagasy and African rubber production during the years from 1943-1945, simultaneous with the dramatic fall in the output from Asian hevea plantations. This fall can be explained by the Japanese occupation of Southeast Asia from 1942 during which they took control of around $90 \%$ of the Asian hevea plantations (Bouvier, 1947). Rubber production in the occupied countries (Malaysia, Dutch East Indies, Thailand and French Indochina) dropped henceforth from 1,390 tonnes in 1941 to 21 tonnes in 1945 (Bouvier, 1947). As a result, the Western powers turned to the past production zones of forest rubber in order to compensate for the deficit in primary material.

When the USA entered the war on the 7 th December 1941 , rubber was considered a strategic material, the absence of which represented a serious threat to national security. The Rubber Survey Committee was created in 1942 and the country signed an agreement with Brazil aimed at reviving production in the Amazonian forest, as well as promotion of guayule in the Sertao area (Dean, 1987; Serier, 1993). This agreement put Brazil under obligation to revive its natural rubber producing sector from a population estimated at two hundred million naturally growing heveas, which were to be harvested by a veritable army of "troops of rubber". The rubber produced was exported exclusively to the USA and thus the whole of Central and South America was engaged in the war effort producing rubber for the USA (Dean, 1987).

The British and French African colonies (French Equatorial Africa and French West Africa gained independence in 1940 and 1942 respectively) (Thobie et al., 1990) revived their productions of forest rubber (which underwent the same development and recession as Malagasy rubber). The Belgian Congo produced 9,400 tonnes of forest rubber in 1944 (Serier, 1993).

As for Madagascar, a six-month long military campaign (from May to November 1942) by British and South African troops culminated in the surrender of the French Vichy government, after which the island was placed under Gaullist occupation (Brown, 2000). At the beginning of 1943 , General Legentilhomme, the new governor of Madagascar, undiplomatically declared "there is an obligation for the natives to contribute to the war through restored discipline, increase in the output of labour and maximisation of productivity" (Thobie et al., 1990). This war effort was accomplished by recourse to forced labour, the requisitioning of harvests (in particular, rice) and the resumption of natural rubber collection (François, 1945; Guillermin, 1947; Moranche, 1947; Thobie et al., 1990; Brown, 2000).

In 1942, when the war effort became a national priority, there was a change in naturalist discourse. A Rubber Committee ("Comité du Caoutchouc") was created which published in 1943 and 1944 instructions "for maximising production of the best quality Malagasy rubber". The botanist Pierre Boiteau distributed at the time, under the seal of the Governor General of Madagascar, a study on the Malagasy rubber species, which could be read as a guide destined for use by farmers (Boiteau, 1943). These documents ironically make no reference to the alarmist scientific publications of the previous years. The legislative corpus was more concerned then with providing a framework for the promotion of rubber collection. An order providing for the regulation of the exploitation, trade and distribution of rubber in the colony and dependencies of Madagascar was instituted on $3^{\text {rd }}$ November 1942. It authorised, in blatant contradiction of the previous discourse, native cooperatives to exploit rubber plants in the national forests, which were neither allocated, nor classified as natural reserves. It regulated the methods of harvesting and preparing the rubber: uprooting and felling prohibited trees, obligation to cut the lianas at ground level and tap the trees, obligation to prepare the rubber in folds, ban on mixing different latexes, authorisation of only two methods of coagulation; acid or heating. Hence, natural rubber production was revived from 1942, with output peaking at 812 tonnes in 1944 (figure 3), yet representing only $0.2 \%$ of world output, compared to the 24,000 tonnes produced in Brazil in 1943 (Deans, 1987). And so, after twenty years of alarmist discourse predicting the irreversible destruction of the ecosystems, the Malagasy forests were once more producing rubber. The same went for the forests of the French African colonies (Aubréville, 1949). At that same time (1943), it is worth noting that the USA attempted to cultivate a species of Malagasy rubber, Cryptostegia grandiflora (Compagnon, 1986), in Haiti.

\section{Today history repeats itself but lessons are soon forgotten}

The birth, rise and subsequent extinction of the rubber sector, at the turn of the $20^{\text {th }}$ century, was the first case of exploitation and exportation of a natural Malagasy resource for industrial ends. The setting up of this sector coincided with the development of naturalist and conservationist thinking, which is still dominant to this day (Kull, 2000).

Today a similarity can be observed in the determination by politicians to ensure the preservation of the Malagasy biological heritage. Madagascar was one of the first countries in the world to equip itself with a network of nature reserves, starting in 1927 (Kull, 1996).

There is continued evidence of this in recurrent proposals for the creation of new protected sites (ANGAP, 2001; Randrianandianina et al., 2003 ; Nohatrarivo, 2004). Likewise, the Durban Declaration of September 2003, made by the head of state during the world congress on protected areas, announcing his determination to extend the coverage of Madagascar Protected Area System from 1.7 million hectares to more than 6 million hectares decreed on $17^{\text {th }}$ October 2008, follows in the same vein. This objective mobilises numerous local and international capabilities (BorriniFeyerabend and Dudley, 2005a, 2005b). These observations highlight a paradoxical situation in which, despite an early awareness of the need, and constant efforts over the past 80 years, to preserve Madagascar's biological heritage, the situation is judged at present to be critical. This ranks Madagascar amongst the "hottest hotspots" of global biodiversity (Myers et al., 2000).

Finally, in a last observation, it can be noted that once launched, the process elaborated during the rubber producing enterprise: revealing the value of a natural resource, its 
exploitation, and subsequent impoverishment of the biological heritage, proved irreversible. All the fine discourses and attempts at sustainably managing the ecosystems, domesticating high performing species and installing cultivation based on high-potential exotic species were ineffective at arresting the process. Consequently, beyond proposing technical solutions for prolonging the Malagasy rubber sector, no apparent determined efforts in the economic sphere for investment in the field ever materialised. The transition from a context of instantly profitable, investment free rubber collected by a native workforce, in a de facto context of free access to the resource, towards one involving the establishment of cultivation with an unpredictable return on investment did not come about. Guaranteeing the protection of Malagasy rubber species has not been accomplished by scaremongering, repressive legislation, or networks of protected areas, but by pure economic realism, which has simply condemned an area of production that has become unprofitable. This is not a new or recent observation, but one which has already been put forward in relation, for example, to the extraction of rubber in Amazonia (Homma, 1992). And yet, sadly, whist the history of rubber is one that has been forgotten, one need only substitute Prunus africana for rubber to see the whole sorry scenario repeating itself, as the bark is exploited for its therapeutic properties in the treatment of benign prostatic hyperplasia in northern hemisphere countries (Stewart, 2003; Péchard et al., 2005). This species is now classified on Appendix II of the CITES... And maybe tomorrow, it will be the turn of tsiperifery, Malagasy wild pepper, recently come to the attention of the world's top chefs and luxury spice merchants alike, the unhindered collection of which is beginning to cause concern (QualiREG, 2011; Ceuppens, 2014).

\section{Acknowledgements}

This study was conducted by the Dispositif de Recherche et d'Enseignement en Partenariat "DP Forêts et Biodiversité", a collaboration between the University of Antananarivo, the Fofifa, and the Cirad. It was supported by the French Ministry of Foreign Affairs ("Forma" and "Parrur" FSP projects). Thanks to the NGO Words for Solidarity for translation services.

\section{Bibliographical references}

ANGAP (Association nationale pour la Gestion des Aires protégées), 2001. Plan de gestion du réseau national des aires protégées de Madagascar. Antananarivo, ANGAP.

Anonymous, 2006. A history of Kruger National Park. http:// www.ecoafrica.com/krugerpark/kruger-history.htm, Accessed 21 March 2012.

Armand E., 1901. Des différents procédés de coagulation du caoutchouc. Bulletin économique de Madagascar, 4 : 275-280.

Aubréville A., 1949. Les forêts. In : Afrique occidentale française. Tome premier, Guernier E. (Ed.). Paris, Encyclopédie coloniale et maritime, 371-390.

Baron R., 1890. A Malagasy forest. The Antananarivo Annual, 14: 196-211.
Bégué L., 1966. La végétation de Madagascar. Bois et Forêts des Tropiques, 106 : 56-65. http://bft.cirad.fr/cd/ BFT 106 56-65.pdf

Bergeret A., 1993. Discours et politiques forestières coloniales en Afrique et à Madagascar. Revue française d'Histoire d'Outre-mer, $79: 23-47$.

Besson L., 1908. Le caoutchouc à Madagascar. Compterendu des travaux du Congrès colonial de Marseille, 1906, $4: 159-168$.

Bigorne J., 1931. La forêt de Madagascar. Bulletin économique du Gouvernement de Madagascar et Dépendances, $58: 59-66$.

Boiteau P., 1943. Les Caoutchoucs de Madagascar. Tananarive, Gouvernement général de Madagascar.

Bonneuil C., Kleiche M., 1993. Du jardin d'essais colonial à la station expérimentale, 1880-1930. Montpellier, Cirad.

Borrini-Feyerabend G., Dudley N., 2005a. Elan Durban... Nouvelles perspectives pour les aires protégées à Madagascar. Antananarivo, WCPA, CEESP and IUCN.

Borrini-Feyerabend G., Dudley N., 2005b. Les aires protégées à Madagascar : bâtir le système à partir de la base. Rapport de la seconde mission UICN (version préliminaire). Antananarivo, WCPA, CEESP, IUCN.

Bourdariat A. J., 1911. Les forêts de Madagascar, leur mise en valeur. Compte rendu du Congrès de l'Afrique orientale, Paris, 9-14 octobre 1911.

Bouvier R., 1947. Le caoutchouc - Brillante et dramatique histoire de l'hévéa. Paris, Flammarion.

Brown M., 2000. A History of Madagascar. Cambridge, Damien Tunnacliffe.

Canaby M., 1932. Le caoutchouc de cueillette à Madagascar. Revue de Botanique appliquée et d'Agriculture tropicale, 12 : 609-621.

Ceuppens Q., 2014. Madagascar wild pepper at risk. http:// www.agriculture-biodiversite-oi.org/en/Nature-agriculture/News-from-the-field/Articles/Madagascar-wild-pepper-at-risk, Accessed 17 March 2016.

Chapotte, 1898. L'agriculture et les forêts dans le Sud de Madagascar. Agriculture, 1 : 161-193.

Chevalier A., 1921. Situation de la production de caoutchouc en 1921. Revue de Botanique appliquée et d'Agriculture coloniale, 1 : 33-103.

Chevalier A., 1926. Le caoutchouc africain et son avenir. Revue générale du Caoutchouc, $21: 29-32,22: 22-24,23$ : 25-28, $25: 16-20,26: 25-28$.

Chevalier A., 1930. L'agronomie coloniale et le Muséum d'histoire naturelle. Revue de Botanique appliquée et d'Agriculture tropicale, $10:$ 425-552.

Chevalier A., 1946. Cinquante années d'efforts scientifiques et sociaux pour le développement de l'agriculture malgache. Revue internationale de Botanique appliquée et d'Agriculture tropicale, $26: 333-351$.

Chevalier A., Le Bras J., 1949. Le caoutchouc. Paris, Presses universitaires de France, Collection « Que sais-je ? ».

Claude P. E., 1909. La situation commerciale de Madagascar pendant l'année 1909. Bulletin économique de Madagascar, 9 : 469-486. 
Coïc A., 2000. La grande aventure du caoutchouc en Amazonie. Bois et Forêts des Tropiques, 264 : 61-66. http://bft. cirad.fr/cd/BFT 264 61-66.pdf

Comité du Caoutchouc, 1943. Le caoutchouc - Instruction pour la production maxima de la meilleure qualité de caoutchouc à Madagascar. Tananarive, Gouvernement général de Madagascar et Dépendances.

Comité du Caoutchouc, 1944. Instruction pour la manipulation, le séchage, la conservation et le transport des caoutchoucs préparés. Tananarive, Gouvernement général de Madagascar et Dépendances.

Compagnon P., 1986. Le caoutchouc naturel. Paris, Éditions G. P. Maisonneuve et Larose.

Constantin J., Galland I., 1907. Quelques plantes à latex de Madagascar. Revue de Madagascar, 9 : 203-208, 247-252.

Coudreau J., 1937. La forêt malgache, son rôle dans l'économie générale du pays, sa conservation, son amélioration. Bulletin économique du Gouvernement de Madagascar et Dépendances, 9 : 75-96.

Dean W., 1987. Brazil and the Struggle for Rubber. Cambridge, Cambridge University Press.

Decary R., 1926. La protection de la faune et de la flore à Madagascar. Revue d'Histoire naturelle appliquée, 7 : 148-160.

Decary R., 1962. L'histoire du caoutchouc malgache. Bulletin de Madagascar, 12 : 987-992.

Decary R., 1966. Les emplois des Euphorbiacées malgaches. Journal d'Agriculture tropicale et de Botanique appliquée, $13: 467-473$.

Delmas P., Duffart C., 1908a. Rapport sur les travaux des deux sections réunies du commerce du caoutchouc et des cultures industrielles. Compte-rendu des travaux du Congrès colonial de Marseille, 1906, 4 : 108-139.

Delmas P., Duffart C., 1908b. Régions de production du caoutchouc. In: Actes de l'Institut colonial de Bordeaux. Congrès colonial de Bordeaux, 4-8 août 1907. Bordeaux, Institut colonial, 89-97.

Donques G., 1975. Les cyclones tropicaux des mars malgaches. Mise au point. Madagascar, Revue de Géographie, $27: 9-63$.

Dove M. R., 1995. Political versus techno-economic factors in the development of non-timber forest products: lessons from a comparison of natural and cultivated rubbers in Southeast Asia and South America. Society and Natural Resources, 8: 193-208.

Drake del Castillo E., 1902. Botanique. In : Madagascar au début du XXe siècle, Paris, Société d’Éditions scientifiques et littéraires, 109-156.

Dubard M., 1906. Contribution à l'étude du genre Mascarenhasia. Bulletin de la Société botanique de France, 53 : 254265, 294-308.

Dumont d'Urville J., 1848. Voyage autour du monde. Paris, Furne et Cie.

Durand A., 1908. Le caoutchouc à Madagascar. In : Actes de l'Institut colonial de Bordeaux. Congrès colonial de Bordeaux, 4-8 août 1907. Bordeaux, Institut colonial. 97-108.

Dybowski J., 1897. Les jardins d'essais coloniaux. Paris, Hachette.
Etesse M., 1913. Le caoutchouc en Casamance. Le Caoutchouc et la Gutta-Percha, 107 : 6904-6907.

Fauchère A., 1911. La question du caoutchouc. Bulletin économique de Madagascar, $1: 1-17$.

Fayol A., 1909. Le caoutchouc. Paris et Liège, Librairie polytechnique Ch. Béranger.

Fournier L., Andriamiarana R., Serier J. B., 1990. Le caoutchouc à Madagascar, histoire et actualité. Caoutchoucs et Plastiques, 699 : 115-120.

François E., 1945. Le commerce extérieur de Madagascar en 1944. La Revue de Madagascar, numéro spécial, 26-30.

Fremigacci J., 1998. La forêt de Madagascar en situation coloniale : une économie de la délinquance (1900-1940). In : Plantes et paysages d'Afrique - Une histoire à explorer, Chastanet M. (ed.). Paris, Karthala et Centre de Recherches Africaines, 411-439.

Gade D. W., 1996. Deforestation and its effects in highland Madagascar. Mountain Research and Development, 16: 101-116.

Galliéni J., 1908. Neuf ans à Madagascar. Paris, Librairie Hachette et Compagnie.

Gautier L., Goodman S. M., 2003. Introduction to the flora of Madagascar. In: The natural History of Madagascar, Goodman S.M. and J. P. Benstead (eds). Chicago and London, The University of Chicago Press, 229-250.

Girod-Genet L., 1898. Les végétaux producteurs de caoutchouc à Madagascar. Notes, Reconnaissances et Explorations, 4 : 999-1015.

Girod-Genet L., 1899. Les forêts à Madagascar. Notes, Reconnaissances et Explorations, 5 : 51-85.

Griess, 1907. Étude sur le caoutchouc à Madagascar. Bulletin économique de Madagascar, 1 : 8-23.

Guillermin A., 1947. Les produits forestiers. In : Madagascar. Tome premier, E. Guernier and G. Froment-Guieysse (eds). Paris, Encyclopédie de l’Empire français, 34-42.

Haevermans T., 2003. Euphorbia. In: The natural History of Madagascar, Goodman S.M. and J. P. Benstead (eds). Chicago and London, The University of Chicago Press, 384-391. Hamet H., Josse L., 1913. Contribution à l'étude du caoutchouc dans le nord de Madagascar. Le Caoutchouc et la Gutta-Percha, 107 : 6899-6904.

Heim R., 1935. L'état actuel des dévastations forestières à Madagascar. Revue de Botanique appliquée et d'Agriculture tropicale, $15:$ 416-418.

Homma A. K. O., 1992. The dynamics of extraction in Amazonia: a historical perspective. Advances in Economic Botany, 9: 23-31.

Humbert H., 1927. La destruction d'une flore insulaire par le feu. Principaux aspects de la végétation à Madagascar. Mémoires de l'Académie Malgache, 5 : 1-78.

Humbert H., 1933. Parcs nationaux et réserves naturelles en Afrique et à Madagascar. Bulletin de l'Association française pour l'Avancement des Sciences, novembre, 211-215.

Humbert H., 1955. Les territoires phytogéographiques de Madagascar : leur cartographie. Année biologique, série 3, 31 : 439-448.

IRSG (International Rubber Study Group), 1996. World rubber statistics historic handbook 1900-1960. Wembley, IRSG. 
IUCN (International Union for Conservation of Nature and Natural Resources), 2015. IUCN Red List of Threatened Species. Version 2010.4. www.iucnredlist.org, Accessed 31 March 2015.

Jarosz L., 1993. Defining and explaining tropical deforestation: shifting cultivation and population growth in colonial Madagascar (1896-1940). Economic Geography, 69: 366-379.

Jeannot E., 1901. Les ressources végétales naturelles de la région Betsimiraka-Betanimena. Paris, Bibliothèque des Cultures coloniales.

Jumelle H., 1901. Les plantes à caoutchouc du Nord-Ouest de Madagascar. Revue générale de Botanique, 13 : 289306, 352-362, 390-401.

Jumelle H., 1903. Les plantes à caoutchouc et à gutta dans les colonies françaises. Paris, Éditeur Augustin Challamel.

Jumelle H., 1912. Le Cryptostegia grandiflora et son caoutchouc. Journal d’Agriculture tropicale, 138 : 358-360.

Jumelle H., Perrier de la Bâthie H., 1908. Une nouvelle Asclépiadée à caoutchouc à Madagascar. Bulletin économique de Madagascar, 8 : 281-285.

Jumelle H., Perrier de la Bâthie H., 1909. Les Landolphia et les Mascarenhasia à caoutchouc du Nord de l'Analalava. Bulletin du Jardin colonial, 9 : 9-26, 111-122, 192-200.

Jumelle H., Perrier de la Bâthie H., 1910. Les plantes à caoutchouc du Nord de Madagascar. Bulletin du Jardin colonial, $10: 184-196$.

Jumelle H., Perrier de la Bâthie H., 1911. Les plantes à caoutchouc de l'Ouest et du Sud-Ouest de Madagascar. Bulletin du Jardin colonial, 11 : 177- 193.

Jumelle H., Perrier de la Bâthie H., 1912. Quelques Landolphia à caoutchouc de l'Est de Madagascar. Bulletin du Jardin colonial, $12: 89-98$

King V. T., 1988. Social rank and social change among the Maloh of West Kalimantan. In: The real and imagined role of culture in development. Hawai, University of Hawai, 219-253.

Kull C. A., 1996. The evolution of conservation efforts in Madagascar. International Environmental Affairs, 8: 50-86.

Kull C. A., 2000. Deforestation, erosion and fire: degradation myths in the environmental history of Madagascar. Environment and History, 6: 423-450.

Lacroix A., 1938. Notice historique sur quatre botanistes membres ou correspondants de l'Académie des Sciences ayant travaillé pour la France d'Outre-Mer de la fin du siècle dernier à nos jours. Paris, Institut de France, Académie des sciences, Gauthier-Villars.

Lavauden L., 1931. Le déboisement et la végétation de Madagascar. Revue de Botanique appliquée et d'Agriculture coloniale, $11: 817-824$.

Lavauden L., 1934. Histoire de la législation et de l'administration forestière à Madgascar. Revue des Eaux et Forêts, 72 : 949-960.

Lavauden L., 1941. Les forêts coloniales de la France. Revue de Botanique appliquée et d'Agriculture tropicale, 21 : 285365, 509-622, 671-752.
Léandri J., 1952. Les arbres et grands arbustes malgaches de la famille des Euphorbiacées. Le Naturaliste malgache, $4: 47-82$.

Lecat P., 1951. L’hévéa fera-t-il la fortune de Madagascar? Entreprises et Produits de Madagascar, 9 : 83-99.

Lecomte H., 1929. Des « réserves naturelles » dans les colonies françaises - Un commencement d'exécution. Revue d'Histoire naturelle, $10:$ 257-274.

Lecomte L., 1899. L'Hazondrano à Madagascar. Revue des Cultures coloniales, 5 : 33-37.

Loisy, 1914. Madagascar - Étude économique. Paris, Éditeur Augustin Challamel.

Louvel M., 1910. Les forêts de la presqu'île Masoala. Bulletin économique de Madagascar, 1 : 30-48.

Mabberley D. J., 1987. The Plant-Book. Cambridge, Cambridge University Press.

MBG (Missouri Botanical Garden), 2010. Tropicos on Web. http://www.tropicos.org/, Accessed 16 April 2010.

McConnell W. J., 2002. Madagascar: Emerald isle or paradise lost? Environment, 44: 10-22.

Mooibroek H., Cornish K., 2000. Alternative sources of natural rubber. Applied Microbiology and Biotechnology, 53: 355-365.

Moranche R., 1947. Les forêts. In : Madagascar. Tome premier, E. Guernier and G. Froment-Guieysse (eds). Paris, Encyclopédie de l'Empire français, 23-34.

Myers N., Mittermeier R. A., Mittermeier C. G., da Fonseca G. A. B., Kent J., 2000. Biodiversity hotspots for conservation priorities. Nature, 403: 853-858.

Péchard G., Antona M., Aubert S., Babin D., 2005. Ressources phytogénétiques, contrats et application de la Convention biodiversité à Madagascar : une approche prospective. Bois et Forêts des Tropiques, 284: 45-57. http://bft.cirad.fr/cd/ BFT 284 45-58.pdf

Penot E., 2001. Stratégies paysannes et évolution des savoirs : l'hévéaculture agro-forestière indonésienne. Thèse de doctorat, Montpellier, Université Montpellier, Faculté des Sciences Économiques.

Perrier de la Bâthie H., 1910. Observations sur Pirahazo (Euphorbia Pirahazo) (Jumelle). Bulletin économique de Madagascar, 2 : 247-250.

Perrier de la Bâthie H., 1912. Les plantes à caoutchouc du versant Ouest de Madagascar. Bulletin économique de Madagascar, 2 : 1-18.

Perrier de la Bâthie H., 1921. La végétation malgache. Annales du Musée Colonial de Marseille, 9 : 1-266.

Perrier de la Bâthie H., 1928. Les bois d'ébénisterie de la Côte ouest de Madagascar. Revue de Botanique appliquée et d'Agriculture coloniale, $8: 469-477$.

Perrier de la Bâthie H., 1931. Les réserves naturelles de Madagascar. La Terre et la Vie, 427-442.

Perrier de la Bâthie H., 1936. Biogéographie des plantes de Madagascar. Paris, Société d'Éditions géographiques, maritimes et coloniales.

Perrier de la Bâthie H., Duchêne G., 1908. Le Ceara sur la côte Nord-Ouest. Bulletin économique de Madagascar, 1 : 14-20. 
Perrier de la Bâthie H., Jumelle H., 1907. Les feux de brousse et la culture des plantes à caoutchouc à Madagascar. Le Caoutchouc et la Gutta-Percha, 36 : 821-824.

Petit G., 1928. L'organisation des Réserves naturelles à Madagascar. Revue de Botanique appliquée et d'Agriculture coloniale, 8 : 272-274.

Piolet J. B., 1901. De l'exploitation et de la culture du caoutchouc à Madagascar. Revue des Cultures coloniales, 11 : 131-136, 174-177.

Poisson H., 1908. Note sur les plantes à caoutchouc et à latex du sud et du sud-est de Madagascar. Revue générale de Botanique, $21: 8-31$.

Pollini J., 2011. The difficult reconciliation of conservation and development objectives: the case of Malagasy Environmental Action Plan. Human Organization, 70: 74-87.

Pouchepadass J., 1993. Colonisation et environnement. Revue française d'Histoire d'Outre-mer, 80 : 5-22.

Prudhomme E., 1899/1900. Le caoutchouc sur la côte est de Madagascar. Revue de Madagascar, 1 : 366-384, 2 : 43-52.

QualiREG (Qualité pour le Développement en océan Indien), 2011. Le poivre à queue. http://www.qualireg.org/actions/ valorisation-des-produits-regionaux/epices/reconnaissance-de-l-origine/les-poivres-sauvages/(language)/fre-FR, Accessed 17 February 2011.

Randrianandianina B. N., Andriamahaly L. R., Harisoa F. M., Nicoll M. E., 2003. The role of protected areas in the management of the Island's biodiversity. In: The natural History of Madagascar, Goodman S. M. and Benstead J. P. (eds.). Chicago and London, The University of Chicago Press, 1423-1432.

Rey (capitaine), 1905. Les richesses forestières du Menabe septentrional. Bulletin économique, 2 : 405-413.

Rochon A. M., 1791. Voyage à Madagascar et aux Indes orientales. Paris, Prault, Imprimeur du Roi.

Scales I. R., 2012. Lost in translation: conflicting views of deforestation, land use and identity in western Madagascar. The Geographical Journal, 178: 67-79.

Schatz G. E., 2001. Generic Tree Flora of Madagascar. Kew, Royal Botanic Gardens and Missouri Botanical Garden.

Serier J. B., 1993. Histoire du caoutchouc. Paris, Éditions Desjonquères.

Stewart K. M., 2003. The African cherry (Prunus africana): can lessons be learned from an over-exploited medicinal tree? Journal of Ethnopharmacology, 89: 3-13.

Thiry M., 1903. Étude sur les plantes à caoutchouc du NordEst de Madagascar. Bulletin économique de Madagascar, 1 : 1-14, 2 : 111-135, $3:$ 215-234.

Thobie J., Meynier G., Coquery-Vidrovitch C., Ageron C. R., 1990. Histoire de la France coloniale, 1914-1990. Paris, Armand Colin.

Tixier P., 1982. Le caoutchouc à Madagascar. Bulletin de l'Académie malgache, 56 : 119-126.

Tralboux (capitaine), 1902. Note sur les caoutchoucs, gommes et résines dans le cercle de Morondava. Bulletin économique de Madagascar, 1 : 251-256.
Vacher (capitaine), 1907. Le caoutchouc dans l'extrême sud malgache. Bulletin économique de Madagascar, 2 : 128-141.

Vergely, 1907. Le caoutchouc dans la province de Farafangana. Bulletin économique de Madagascar, 3 : 264-266.

Weinstein B., 1983. The Amazon Rubber Boom 1850-1920. Stanford, Stanford University Press.

Zimmermann M., 1899. La forêt à Madagascar. Annales de Géographie, 37 : 74-82.

\section{Archival sources}

Bührer, 1909. Notice sur les plantes à caoutchouc à Madagascar. Fonds Grandidier, Antananarivo, cote 2969.

Nohatrarivo M., 2004. «Une centaine de nouveaux sites Madagascar parie sur les aires protégées ». L’Express de Madagascar, $17^{\text {th }}$ April 2004.

Perrier de la Bâthie H., 1912a. Rapport au Chef de Service de Colonisation. 23rd October 1912. Archives de la République de Madagascar, D70s.

\section{Orders and Ministerial orders}

Order dated $3^{\text {rd }}$ July 1897 . Arrêté portant réglementation du droit d'exploitation de produits de la forêt. Bulletin officiel de Madagascar et de ses Dépendances.

Ministerial order dated $10^{\text {th }}$ February 1900 . Décret établis sant le régime forestier applicable à la colonie de Madagascar et Dépendances. Journal officiel de Madagascar et Dépendances.

Order dated $20^{\text {th }}$ September 1907 . Arrêté réglementant l'exploitation des produits forestiers. Journal officiel de Madagascar et Dépendances.

Ministerial order dated $28^{\text {th }}$ August 1913. Décret fixant le régime forestier à Madagascar. Journal officiel de Madagascar et Dépendances.

Ministerial order dated $31^{\text {st }}$ December 1927. Décret portant création de réserves naturelles à Madagascar. Journal officiel de Madagascar et Dépendances.

Order dated $3^{\text {rd }}$ November 1942. Arrêté portant réglementation de l'exploitation, la vente et la circulation du caoutchouc dans la colonie de Madagascar et Dépendances. Journal officiel de Madagascar et Dépendances.

Interministerial order dated $17^{\text {th }}$ October 2008. Arrêté inter-

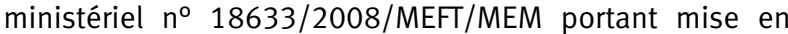
protection temporaire globale des sites visés par l'Arrêté interministériel $n^{\circ} 17914$ du 18 octobre 2006 et levant la suspension de l'octroi des permis miniers et forestiers pour certains sites. Journal officiel de Madagascar. 